\title{
Determinants of Outstanding Mortgage Loan to Value Ratios: Evidence from the Netherlands*
}

\author{
M. Ricardo Cunha, Bart M. Lambrecht and Grzegorz Pawlina
}

December 17, 2009

\begin{abstract}
This paper studies the determinants and behavior of outstanding mortgage loan to value (LTV) ratios for a panel data set of 5,179 households over the period 1992-2005. We find that outstanding LTVs are driven by household characteristics, life-cycle effects and mortgage type characteristics. LTV declines with the time elapsed since mortgage commencement, but its level is consistently higher (by around 10\%) for non-repayment mortgages (such as interest-only or endowment mortgages) than for repayment mortgages (such as linear or annuity mortgages). The difference results from higher debt capacity associated with the possibility of deferring the principal repayment for non-repayment mortgages. Our results indicate that the recent proliferation of non-repayment mortgages is driven by tightening financing constraints due to declining affordability in the housing market and that the overall quality of outstanding mortgages has substantially deteriorated over the last decade.
\end{abstract}

Keywords: housing finance; mortgages; leverage choice (JEL: C21, D14, G21)

\footnotetext{
${ }^{*}$ Cunha is from Portuguese Catholic University, Porto, and gratefully acknowledges financial support for his doctoral studies from Fundacao para a Ciencia e Tecnologia. Lambrecht and Pawlina are from the Department of Accounting and Finance, Lancaster University, UK, and thank the ESRC (grant RES-062-23-0078) for financial support. We also thank participants of EFA (Bergen), AREUEA (Istanbul), BAA (Blackpool), Maastricht-MIT-Cambridge Real Estate Finance and Investment Symposium, Portuguese Finance Network conference (Coimbra), and Warsaw International Economic Meeting for helpful comments and suggestions. Correspondence can be sent to g.pawlina@lancaster.ac.uk.
} 
For a number years we have witnessed an increase in homeownership rates and in the amount of aggregate mortgage debt both in the US and across the world (e.g., Li (2005) and OECD (2006a)). The very easy access to credit and the proliferation of more flexible mortgage products have made mortgages available to households that would not be able to afford a house a few decades ago.

The recent rise in home foreclosures and the 'subprime' mortgage crisis have, however, drawn attention to a number of worrying developments and trends in mortgage lending. In particular, there has been a notable increase in recent years in lending to high-risk, so-called subprime, borrowers as well as a rise in non-performing mortgages (see Demyanyk and Van Hemert (2008)). Loan incentives such as 'interest-only' mortgages, low initial 'teaser' rates, repayment holidays and laxer lending criteria are frequently cited as having encouraged borrowers to take on more debt than they can handle.

The situation in the housing market has a considerable effect on the whole economy. The aggregate value of the owner-occupied housing stock in the US increased from $\$ 2.8$ trillion in 1982 to $\$ 7.3$ trillion in 1999 (see Case (2000)), which is comparable with half of the American stock market capitalization. Consequently, any wave of households entering into negative equity, resulting bankruptcies and forced sales would all feed back into the stability of the financial system, consumer demand and, in general, economic growth itself. A proper understanding of the riskiness of household mortgage debt is therefore key to assessing measures and designing policies aimed at preserving the stability of the economic growth. Since mortgages are secured by the value of the house, the mortgage credit risk is in the first instance determined by the ratio of the outstanding mortgage debt to the value of the house, commonly known as the loan-to-value (LTV hereafter). ${ }^{1}$

The academic literature has, however, devoted surprisingly little attention to the analysis of outstanding LTV. To quote Follain (1990) in his presidential address to the AREUEA: "Although much has been written about the aggregate demand for mortgages, housing economists do not seem to have picked up on what many financial economists have made a career of doing - explaining debt-equity ratios." ${ }^{2}$ In his

\footnotetext{
${ }^{1}$ Von Furstenberg (1969) was one of the first to show that the loan-to-value ratio governs the level of default rates over the life of the mortgage. He found that reducing the downpayment in the highest LTV range by as little as $1 \%$ of home value can cause default rates to rise by $50 \%$. More recently, Demyanyk and Van Hemert (2008) show that in the run-up to the mortgage crisis high LTV borrowers became increasingly riskier compared to low LTV borrowers.

${ }^{2}$ The few exceptions include Englund, Hendershott, and Turner (1996), who study the effect on
} 
presidential address to the AFA, Campbell (2006) states that household finance is an underresearched area and he points out the lack of good quality data as one of the main reasons.

This paper aims to address this gap and presents an empirical study on housing finance. As detailed international micro-level data of housing finance is not readily available, we test our hypotheses using a detailed survey data from the Netherlands. As we motivate later, the characteristics of the economic and legal framework in the Netherlands allow us readily to generalize many of our conclusions to other countries (see Guiso, Sapienza, and Zingales (2008), who use data from the same survey). Our paper addresses the following questions. What are the determinants of LTV for homeowners who have outstanding mortgage debt? How does LTV vary over a household's lifecycle? How has the proliferation in recent years of mortgages without compulsory amortization (such as 'interest-only' mortgages) affected LTVs and what are their longterm consequences for LTV ratios? What are the characteristics of households that choose a mortgage product without compulsory amortization and have they changed over time? And, finally, are higher LTV ratios and repayment flexibility reflected in mortgage interest rates?

While there is vast theoretical and empirical evidence that corporations follow some optimal leverage level, we find that for households outstanding LTV declines as the time from mortgage commencement elapses. Amortization of the mortgage debt is one obvious reason. Appreciation in the value of the house may be another one. There appears to be little or no evidence that the initial LTV at mortgage commencement is anything like an intertemporal optimum that households seek to maintain. Moreover, the dispersion in outstanding LTVs is quite large (especially compared to the variation in corporate leverage ratios). A histogram of outstanding LTV ratios in our study reveals that the average LTV of households with outstanding mortgage debt in our sample is 0.497 with a standard deviation of 0.270 . Importantly, more than $15 \%$ of the homeowners in our sample do not have any outstanding mortgage debt.

What explains this wide dispersion of outstanding LTV across homeowners? We find a pronounced life-cycle effect in LTV in that LTV declines with the time elapsed housing finance of financial deregulation in Sweden during the 1980s based on data on loan-to-value ratios for homeowners that moved recently, and Hendershott and Pryce (2006), who report a substantial decline in LTVs following the abolishment of mortgage interest relief for taxation purposes in the UK. In a related work, Koijen, Van Hemert, and van Nieuwerburgh (2008) investigate the choice between the adjustable and fixed rate mortgages. 
since mortgage commencement. Furthermore, we identify a number of other determinants of LTV. The number of household members is shown to positively affect LTV, whereas a household's net worth (total assets minus total outstanding debt) negatively influences it. This latter effect follows from the fact that households with low net worth are more likely to be financially constrained and may have to rely more heavily on debt financing. Households on social benefits and those facing a higher tax rate also exhibit a higher LTV.

We also show that the mortgage type adopted is an important explanatory variable of outstanding LTV, with non-compulsory repayment contracts being associated with higher levels of debt. One explanation for this may be that the reduction in the outstanding mortgage debt is primarily determined by a compulsory amortization schedule for repayment mortgages, whereas repayment of outstanding debt is left to the discretion of the borrower in the case of non-repayment mortgages. More surprisingly, the wedge in LTV between both mortgage types remains even if one adjusts non-repayment mortgages for the cash value of the savings that have been accumulated in special investment vehicles linked to the mortgage. A striking trend during our sample period is the dramatic increase in the mortgage to income ratio, especially for non-repayment mortgages.

The combination of higher LTV and substantially higher loan-to-income ratios for 'non-repayment' mortgages indicates that these mortgages are potentially riskier than repayment mortgages. This finding is consistent with the fact that the recent surge in mortgage defaults in the US and the UK has been linked primarily to mortgages that share many of the features present in non-repayment mortgages. Why then have so many households chosen to adopt non-repayment mortgages in recent years? We investigate the households propensity to select a non-repayment type mortgage (as opposed to a repayment mortgage) using a binary choice (probit) model and show that the proliferation of non-repayment mortgages has been driven primarily by the dramatic decline in housing affordability. ${ }^{3}$ This is consistent with the observation that over the period of our sample the house price index $\left(H P I_{1994}=100\right)$ rose from 80 in

\footnotetext{
${ }^{3}$ There may, of course, be other reasons for the proliferation of non-repayment mortgages that we do not capture in our study. For example, mortgage brokers typically receive a higher commission on nonrepayment type mortgages and may therefore have incentives to oversell these products. Examples of this behavior are the reported cases in the UK of 'endowment' mortgages that were sold to borrowers for whom this product was inappropriate. These cases prompted an investigation by the Financial Services Authority, who subsequently tightened up the UK code of mortgage lending practice in order better to protect borrowers against this type of misselling.
} 
1992 to 280 in 2005, whereas house affordability (as defined in Appendix A) declined from about 117 in 1992 to about 50 in 2005. Another important reason for the increased popularity in non-repayment mortgages is the tax advantages they confer. Our findings indicate that non-repayment mortgages relax financing constraints and help households to catch up (in the short run at least) with the soaring house prices.

The remainder of the paper is organized as follows. Section 1 discusses empirical hypotheses, Section 2 presents the data set, whereas Section 3 describes the main trends in the Dutch housing market. Section 4 focuses on the univariate analysis, which is followed by the regression analysis of Section 5. Section 6 concludes.

\section{Hypotheses}

While firms and households show many similarities, they are also different in a number of ways. Unlike corporations, households have finite horizons and are likely to be riskaverse. Therefore, we postulate that the household financing decisions are the outcome of the interplay of factors that affect their demand for financing as well as the ability to service debt. Some of the factors are expected to parallel those of corporations, such as net worth, income or education (serving as a proxy for both financial sophistication and the future income generating ability). The other factors we consider are specific to households. Age is expected to be one of key determinants of leverage because the level of mortgage debt tends to decline along the life cycle. Finally, variables such as the number of household members and the degree of urbanization determine the demand for housing so they are likely to affect the LTV ratio as well. Our first empirical hypothesis is therefore:

H1: The LTV ratio is a function of socio-demographic variables, such as income, net worth, education, household size, location as well as the stage in the household's life-cycle.

Mortgage contracts analyzed in our study differ predominantly with respect to repayment flexibility. We classify mortgages into 'repayment' mortgages and 'nonrepayment' mortgages. The former are defined as mortgages that have a compulsory amortization schedule (such as 'annuity' and 'linear' mortgages) and the latter as mortgages that leave discretion with respect to the amortization schedule (such as 'interest-only' mortgages and 'endowment' mortgages). ${ }^{4}$ As the mortgage choice re-

\footnotetext{
${ }^{4}$ For example, with a 'linear' mortgage the periodical payments include paying off the interest on
} 
flects a household's preferences for repayment flexibility, we put forward the following hypothesis:

H2: Flexible mortgages are associated with higher LTV ratios throughout the life of the mortgage.

One obvious motivation for this hypothesis is the fact that the reduction in the outstanding mortgage debt is primarily determined by a compulsory amortization schedule for repayment mortgages, whereas repayment of outstanding debt is left to the discretion of the borrower in the case of non-repayment mortgages. In addition, households who select non-compulsory repayment mortgages self-select to do so and, therefore, are likely to value (and to use) the flexibility their contracts are associated with.

To address the evolution of the LTV rates over time and the associated proliferation of the non-compulsory repayment mortgages, we test three additional hypotheses. First, we point out that it is not always obvious whether a higher LTV implies riskier mortgage debt. Both $i$ ) the higher LTV level and $i i$ ) the proliferation of flexible (i.e., with no compulsory repayment of the principal) contracts may also be a result of sophisticated optimizing investors shifting to the flexible products once they become available in the market. Households on a high income may, for example, adopt flexible non-repayment mortgages because of tax considerations. Our hypothesis is therefore:

H3a: Households adopt flexible contracts in order to exploit the advantages of debt, such as tax savings.

If the non-compulsory repayment contracts are chosen by financially sophisticated households, then their proliferation and the (resulting) higher LTVs are a sign of a rational response of optimizing agents to the emergence of new products. For financially sophisticated households, variables such as education and income will have a positive effect on the probability of selecting flexible mortgages and on the levels of LTV, as they indicate a higher level of wealth and financial sophistication. Moreover, the differences the outstanding loan and a fixed percentage of the total loan. On the other hand, with an 'interestonly' mortgage one pays interest during the term of the mortgage and a large 'balloon' payment at the end. Other mortgages covered by our study are 'traditional life-insurance' mortgages, 'improved life-insurance' mortgages, 'investment' mortgages, 'annuity' mortgages and 'life-insurance' mortgages. The various mortgage types covered in our study are discussed in more detail in Section 3.4. Definitions of each mortgage type can also be found in the Appendix B. Note that the typical distinction between fixed rate and variable rate mortgages is less important in the Netherlands because the overwhelming majority of mortgages are fixed rate mortgages. 
between the characteristics of borrowers choosing standard and flexible contracts should prevail over time. If these are financially sophisticated households who choose the flexible, high LTV products, then the proliferation of non-repayment contracts will generally not be associated with higher credit risk.

The alternative hypothesis is that the flexible contracts (and higher LTV) are mostly selected by financially constrained households, who - otherwise - would not be able to afford a house. In such a case, the proliferation of flexible contracts and the increase in average LTV would be an indicator of higher credit risk.

H3b: Households adopt flexible contracts to alleviate financing constraints.

If the alternative hypothesis H3b is true, then measures of financial constraints are the main determinants of the mortgage type choice. The choice of higher leverage and non-compulsory repayment contracts will be unrelated to marginal tax rates and will not depend (or will depend negatively) on the measures of financial sophistication (such as education). The total pool of mortgage contracts will become more risky over time as the households with worse characteristics follow the wealthier and more sophisticated ones in choosing non-repayment contracts.

Our final hypothesis is related to the potential cost of leverage and of repayment flexibility.

H4: The interest rate increases with the LTV ratio and is higher for non-repayment mortgages.

Households who decide to borrow more or to select a non-compulsory repayment contract may face an upward sloping supply curve of mortgage loans, which translates into higher borrowing rates. In equilibrium, some households may find it optimal to accept higher mortgage interest rates as a price for the benefits of higher borrowing and for the flexibility embedded in the non-repayment contracts. The alternative hypothesis is that higher LTV ratios and flexible contracts are not associated with higher interest rates. If flexible mortgages come at no additional cost, then rational borrowers may prefer them to traditional contracts. This may lead to a proliferation of non-repayment mortgages. 


\section{Data}

The data set used is based on the DNB Household Survey (DHS) carried out by CentERdata, a data collection unit of the Center for Economic Research at Tilburg University (see also Guiso, Sapienza, and Zingales (2008)). The (rotating) panel covers the period 1992-2005, containing end of the year data for a yearly average of over 1000 representative households in the Netherlands, and provides very unique information about the financing, spending, labor and social decisions of individual households. Observations considered are the ones in which all relevant parts of the questionnaire were answered by household members. ${ }^{5}$ The sample therefore comprises 13,546 householdyears (9,422 owners, 4,124 renters), 7,860 of which being borrowers (5,731 with nonrepayment and 2,129 with repayment contracts). For descriptive analysis purposes, the sample is divided in 4 periods (1992-1995, 1996-1998, 1999-2002, and 2003-2005). Households responding to all parts of the questionnaire in several years are considered as different observations. In the regression analysis, we control for the potential correlation of error terms within a household.

All currency-denominated values are expressed in euro (using the official NLG/€ 2.20371 conversion rate), and are in real terms. Inflation correction was made throughout the period for all currency denominated variables, considering the Consumer Price Index (CPI) as deflator. The reference year considered is $1994\left(C P I_{1994}=100\right)$.

Data collection for households and individuals involves several challenges, mainly due to privacy and refusal issues. Still, our data set contains a significant number of observations, a representative demographic spread and a good coverage of the main household variables, such as housing, assets, liabilities, and personal information. Furthermore, an exhaustive categorization within these classes of variables is available, in particular for housing and mortgage variables. Thus, we can assume our sample to be "of quality", according to the requirements postulated in Campbell (2006). ${ }^{6}$

Finally, the economic and legal factors that influence homeownership and housing finance are fairly homogenous across the Netherlands (unlike the United States or Germany, for example, where legislation, taxation and financial policy may vary across

\footnotetext{
${ }^{5}$ We removed extreme outliers as well as implausible observations from the data. The following criteria led to the omission of an observation from the sample: total asset value above $€ 5 \mathrm{~m}$, net income value above $€ 2 \mathrm{~m}$, mortgage interest rate above $20 \%$, house value above $€ 2 \mathrm{~m}$, LTV ratio above 1.5 , and the age of the eldest member of the household (in years) above 100 .

${ }^{6}$ Bucks and Pence (2006) demonstrate the reliability of household surveys by providing empirical support for the accuracy of the house values and mortgage data reported by the US survey respondents.
} 
states). Furthermore, the LTV behavior in the Netherlands have been less distorted by incentives problems of lenders and financial intermediaries. Unlike the US, the practice of passing on credit risk through mortgage securitization is still comparatively rare. As a result incentive and monitoring problems have not been as severe. This is one of the reasons why lending standards have not been loosened as much over time. We believe for the above reasons that the Netherlands is particularly suitable for investigating this paper's research questions (see also Charlier and van Bussel (2003)).

\section{Trends and determinants of housing finance}

\subsection{General trends}

The reported percentage of owner-occupied homes in the Netherlands in 1990, 1994, 1998, 2000, 2002 and 2006 were respectively 45.3\%, 47.6\%, 50.8\%, 52.2\%, 54.0\% and $54.2 \%$ (Ministry of Housing (2002) and CBS). ${ }^{7}$

The increase in the total housing stock has been very modest. Figure 1 shows that the housing stock has merely kept pace with the rising trend in the number of households. The number of households increased from 6.266 million in 1992 to 7.091 million in 2005, whereas the corresponding numbers for the housing stock are 6.043 and 6.912 million, respectively. In contrast, the house price index (HPI) constructed by the Dutch land registry office has risen from 81 in 1992 (with $H P I_{1994}=100$ ) to a spectacular 279 in 2005. This translates into an annual growth rate of about $10 \%$. Furthermore, household income has risen at a much lower pace causing the affordability ratio in 2005 to be less than half its 1992 level. The OECD (2004) reports that housing affordability in the Netherlands (defined as the proportion of available income to house price value) declined more than anywhere else, except for Spain, during the period 1991 to 2002. Brounen, Neuteboom, and van Dijkhuizen (2006) predict that housing affordability in the Netherlands (with an average spending of more than $35 \%$ of income

\footnotetext{
${ }^{7}$ The reported rates are, however, still among the lowest in the European Union. The reason is that traditionally the Netherlands have not had a large owner-occupied housing sector. The Dutch government policy, particularly during the first half of the 20th century was very much focused on stimulating the construction of social housing. However, since the early 90s the Netherlands housing policy has observed a shift, and the main housing policy objective is to promote affordable owner occupation (Ministry of Housing (2002)). Taxation schemes, guarantees, bureaucratic and economic incentives have been implemented as means to promote homeownership. Also, incentives to the conversion of dwellings in the vast social rental scheme to owner occupied dwellings have been introduced.
} 
on housing by the end of 2007) will deteriorate more than in any other European country.

[Insert Figure 1 about here]

While affordability has fallen to a record level, interest repayments as a fraction of disposable income have not increased by as much. The reason is that interest rates have fallen dramatically over the sample period (from $9.27 \%$ in 1992 to $2.09 \%$ in 2005). ${ }^{8}$ Record low interest rates have provided households with access to cheaper credit allowing them to lever up their income aggressively in order to keep up with rising house prices. This is reflected in the substantial increase in the loan-to-income ratio (see section 3.3 ).

With regards to our data, homeownership rates in the sample are somewhat higher than the rates for the Netherlands as a whole. Table 1 shows that owner occupancy rates in our sample are $71.7 \%, 68.7 \%, 67.0 \%$, and $67.8 \%$ for the respective four periods. ${ }^{9}$ About $3 \%$ of households in the total sample own a second house, but this proportion has been declining from $3.7 \%$ in the first sample period to $1.7 \%$ in the last sample period.

[Insert Table 1 about here]

Table 1 also shows that the average initial loan-to-value (i.e. at the time of mortgage commencement) has fallen from $80.3 \%$ to $75.2 \%$ over the period of study. Average

\footnotetext{
${ }^{8}$ The 1992 interest rate refers to the Guilder Market Interest Rate, whereas the 2005 rate refers to the Eurozone Interest Rate.

${ }^{9}$ There are a number of potential reasons why observed ownership rates are higher than the ones observed in the official statistics. It is likely that our sample does not adequately include certain segments of the population that typically do not own their home. For example, homeless or very poor people are under-represented in our sample. Also households that are highly mobile or do not have a fixed residence are less likely to be included in our survey. Elderly people who have sold their home to pay for a room in a care-home would neither appear in our sample. These are all people who typically are unlikely to own their home. Finally, single person households are significantly underrepresented in our sample. Since the homeownership rate is substantially lower for this group (only $42 \%$ ) this creates another upward bias in our ownership rates. We conclude that higher availability of information on housing issues for homeowners may therefore lead to a bias in the questionnaire response rates towards the observed higher proportion of homeowners.
} 
outstanding loan-to-value of households has dropped from $44.4 \%$ to $39.9 \%$. If we take out households without a mortgage then the average loan to value has dropped from $52.9 \%$ in the first period to $44.8 \%$ in the third period, only partially bouncing back in the last period to $48.2 \%$. The drop in outstanding loan-to-value ratios have to be interpreted, however, in the context of inflated house prices, the spectacular rise in loan-to-income ratios and trends in various other determinants of LTV. In fact, our regression analysis in next section shows that, when controlling for other effects, there is a positive time trend in outstanding LTV.

\subsection{Household balance sheet and income: Owners vs. renters}

Table 2 shows the balance sheet for the average homeowner and non-homeowner household. The data are reported in an analogous way as for public corporations whenever possible. Although we have detailed data for assets and liabilities, developing an income statement for households is not possible as information about household consumption and expenses is not disclosed in our data set. ${ }^{10}$

[Insert Table 2 about here]

Starting with homeowners' assets, the balance sheet shows that the house counts for $75.7 \%$ of the assets of the average household in the total sample. Another $1.4 \%$ and $3.5 \%$ are to be attributed to a second house or other real estate investments, respectively. Cash accounts and cash savings together account for another $7.6 \%$. Insurance policies, financial market based savings, money lent and other savings together count for about $7.2 \%$. Vehicles count for $3.9 \%$. Total assets for homeowners amount to $€ 205,860$ on average. In contrast, total assets for non-homeowners are only $€ 22,128$ on average. In the absence of real estate the asset portfolio is much more weighted towards savings and financial investments. Cash accounts and cash savings together count for 49.2\%. Insurance policies, financial market based savings, money lent and other savings together count for another $31.3 \%$. Vehicles make up the remaining $19.5 \%{ }^{11}$

On the liability side household equity (net worth) counts for $66.1 \%$ for homeowners in the full sample. Consequently, the majority of households assets has been financed

\footnotetext{
${ }^{10}$ For a detailed analysis of household portfolios and their international comparisons, see Guiso, Haliassos, and Jappelli (2002).

${ }^{11}$ The above proportions have been fairly constant over time, except that financial market based savings have observed a significant increase in the third period.
} 
by retained income, accumulated wealth, or money transfers such as endowments, donations or inheritance. The mortgage on the house counts for $30.1 \%$. In comparison, the other financing sources are negligibly small. The analysis of external housing finance can therefore safely be restricted to mortgage financing. More than $80 \%$ of house owners finance their property using a mortgage. This fact is consistent with the Income Panel Survey (IPO, Inkomens Panelonderzoek), and with the findings of Alessie, Hochguertel, and van Soest (2002) in their analysis of household assets and liabilities portfolios in the Netherlands.

Net worth of non-homeowners counts for $88.1 \%$ of all liabilities. $5.6 \%$ of assets are financed by short-term extended lines of credit $(4.8 \%)$, overdrafts $(0.6 \%)$ or credit cards $(0.2 \%)$. Medium term financing (mainly private and study loans) count for another $4.5 \%$. Loans from family and friends and other loans count for the remaining $1.8 \% .^{12}$

Home-owning households in our sample have an average total salary of $€ 30,837$, an average gross income of $€ 42,595$, and an average net income of $€ 29,197$. For households that do not own their home these values are substantially lower and respectively given by $€ 18,324, € 26,596$ and $€ 18,917$. In our regression analysis we use adjusted income equivalence values according to the number of household members, which represent a better relative earning position of the household. The equivalence is computed using the Eurostat scale, which considers the first household member with a factor 1, the second 0.5 , and any additional member 0.3. The equivalence values are then equal to per capita values where the number of household members is calculated according to the relevant scale. ${ }^{13}$

[Insert Table 3 about here]

\subsection{Housing finance structure}

Dutch house prices have boomed since the start of our period of analysis. In our sample, average house values rise substantially too during the period of observation. Although our data reflect house values perceived by households and not actual transaction values, research has shown that house values reported by survey respondents are fairly reliable

\footnotetext{
${ }^{12}$ The composition of liabilities has remained fairly stable over time. Mortgage financing has declined somewhat in favor of net worth.

${ }^{13}$ For a detailed discussion of this and other used income equivalence scales see OECD (2006b).
} 
and accurate (see, e.g., Bucks and Pence (2006)). The average real house value for our sample over the full period of study is $€ 171,613$, and grew from $€ 135,104$ in the $1992-95$ period to $€ 242,426$ in the $2003-05$ period. As can be seen from Figure 1, our average sample house values are in line with the house price index.

Figure 2 (Panels B-D) shows frequency histograms of the average initial loan to values (ILTV) and the average loan to values during the periods under consideration. ${ }^{14}$

[Insert Figure 2 about here]

Table 4 documents the evolution of loan-to-income ratios for repayment and nonrepayment mortgages. While for repayment mortgages the ratio remains fairly constant around 1.4, the ratio rises for the increasingly ubiquitous non-repayment mortgages from 1.71 in 1992 to 2.99 in 2005.

[Insert Table 4 about here]

The data shows a clear link between outstanding LTV and age. The average outstanding LTV for homeowners below the age of 35 is 0.62 . This fraction falls approximately by 0.1 for every 10 years of age that is being added, leaving over 65 year old homeowners with an average outstanding LTV of 0.19 . Note that between $80 \%$ to $90 \%$ of all homeowners up to the age of 65 have a mortgage, but only $65 \%$ of owners over 65 have a mortgage. This sudden drop can be explained by the fact that mortgages usually have a 30-year term in the Netherlands.

\subsection{Mortgage types}

Table 5 provides information on the various mortgage types in our data. The definition of each mortgage type is included in Appendix B. As previously explained mortgage types have been divided into two categories: repayment mortgages and non-repayment mortgages. Mortgage types falling into the former category are annuity mortgages and linear mortgages, whereas the latter category includes the various types of lifeinsurance mortgages, endowment mortgages, investment mortgages and interest-only mortgages.

\footnotetext{
${ }^{14}$ When computing the descriptive statistics, we removed observations with an initial loan-to-value of less than 0.1 or more than 1.1. Outstanding loan-to-value observations are not affected by this data selection, and hence no effect from this procedure is found in the regression results of Section 4 .
} 
[Insert Table 5 about here]

Table 5 reports the frequencies for each mortgage type in our sample, as well as the average loan-to-value for each mortgage type. We consider both initial loan-to-values (i.e., upon mortgage commencement) and the loan-to-values at the time of the survey.

Mortgages with a compulsory repayment component accounted for $36.0 \%$ of all mortgages at the start of the sample period. This number had fallen to $12.9 \%$ by the end of the sample period. Life insurance mortgages (and its variants) accounted for $47.3 \%$ at the start of the sample period, and had dropped to $32.3 \%$ for the last period. Most noticeable is the spectacular rise of pure interest-only mortgages which do not feature in a specific category for the first two periods, but amount to $36.6 \%$ of all mortgages in the last period.

Interestingly, average initial loan-to-value in our sample has been consistently between about $70 \%$ and $80 \%$ for all types of mortgages. Cases of initial loan-to-value close and above $100 \%$ do occur, however, as legally no initial loan-to-value limit is imposed in The Netherlands. ${ }^{15}$ Interest-only mortgages, dominant in the last years of the sample, have lower average initial loan-to-values than other mortgage types. Possibly, the absence of compulsory capital repayments (or any other associated investment vehicle that can act as collateral), and the lower collateral for the lender compared to other mortgage types, leads to a higher initial down-payment requirement as a guarantee.

As to be expected, the evolution of the loan-to-value over time varies dramatically across mortgage types: average LTVs decline much faster for repayment mortgages than for those mortgage types that do not have a compulsory repayment of the principal. Average LTVs for the former category are more than $40 \%$ lower than the initial LTV (e.g. the average LTV for annuity mortgages drops from $80 \%$ at commencement to $40 \%$ at the time of the survey). For the latter category this drop is within the range of $20 \%$ to $35 \%$ and the ultimate repayment of the principal when the mortgage expires (or if the housing market were to enter in a recession) remains therefore much more uncertain.

The existence of a lower loan to value and faster repayment for compulsory repayment mortgages is true even if one deducts the cash value of life insurance policies from the outstanding debt in life-insurance type mortgages (life insurance, traditional life insurance, and improved traditional life insurance mortgages). ${ }^{16}$

\footnotetext{
${ }^{15}$ In practice $125 \%$ is, however, considered an upper bound by most lenders.

${ }^{16} \mathrm{In}$ our data set this insurance policy value is reported since 2000. For households reporting positive value in life insurance policies associated to their mortgages, the policy represents on average
} 
Given that mortgages without a compulsory repayment have become much more prevalent in recent years this may have implications for future homeownership. In particular, when the mortgage expires (typically by the time the mortgagee retires, considering the usual 30 year maturity of mortgages in the Netherlands) some of the less wealthy households may have to sell off the property in order to pay off the outstanding debt. Unless a new and smaller house is bought this may lead to a drop in homeownership rates for households that are retired. Brounen and Neuteboom (2006) estimate however that this pressure in homeownership will not be as pronounced as initially expected. In light of the recent US mortgage crisis it should also be noted that mortgages with a higher outstanding LTV may be more exposed to a recession in the housing market.

The increased popularity of non-repayment mortgages may, in part, be due to the tax advantages they confer. Until 1997 interest from all types of household debt (mortgage debt and the different consumer debt types) was tax deductible. Between 1997 and 2000 a phasing out process of the deductibility of consumer debt interest and mortgage interest not associated with the primary residence was implemented. Since 2000 interest tax deductibility has been confined to the main loan used for purchase (and maintenance) of the primary residence but, unlike most other countries, the total deductible value is uncapped. However, interest on consumer debt, mortgages on second homes and on mortgage equity withdrawals are disqualified for tax-shield purposes. The new tax policy therefore makes mortgage debt more attractive than other forms of credit and puts investors in real estate at a disadvantage compared to first-time buyers.

Taxation policy has had an effect on the choice between mortgages with compulsory and non-compulsory principal repayment. Official evidence shows that the concession of tax benefits and guarantees for house owners coincided not only with an increase in owner occupied housing, but also with a wave of re-mortgaging and a shift to more interest-based mortgages (Ministry of Housing (2002)). This latter effect is observed in our sample and was described above. Finally, towards the end of our sample period the banking industry created numerous financial products combining mortgage tax shields and capital gains concessions, which observe high popularity. ${ }^{17}$

$6.5 \%$ and $7.2 \%$ of the total value of the house, respectively, in periods 1999-02 and 2003-05, to which correspond an average corrected loan to value of 0.47 and 0.49 . These corrected loan to value figures are substantially higher than the ones observed for mortgages with compulsory repayment.

${ }^{17}$ In the Netherlands capital gains on personally held assets are not taxed. However, taxable returns on capital assets are set at a presumptive rate of $4 \%$ of the value of the assets, and taxed at a $30 \%$ rate. This taxation scheme is however not valid for owner occupied real estate, where concessions are made 
The government's homeownership policies, increased banking competition and easier access to mortgage debt (e.g. by considering dual income for credit scoring purposes) had not only an effect on homeownership rates, but were also key factors in the evolution of house prices (Brounen, Neuteboom, and van Dijkhuizen (2006)).

\section{Univariate analysis}

To analyze the outstanding mortgage loan to value ratio of households, it is important to recognize that the LTV is only defined for those households that own their home. It is therefore important first to analyze what differentiates homeowners from renters. In this section we define and analyze a number of variables that are traditionally considered to be important determinants of homeownership. We use a univariate analysis and non-parametric tests to explore whether homeowners are inherently different from renters in terms of their characteristics.

Next we focus on the housing finance decision. As will be shown later, the type of mortgage contract adopted (that is, "repayment" mortgage contract versus the flexible "non-repayment" mortgage) has important implications for the level and evolution of the outstanding mortgage LTV. We postpone the explicit modeling of a household's outstanding LTV till later and explore in this section what differentiates homeowners that choose a repayment mortgage from those that adopt a non-repayment mortgage. For this purpose we perform a univariate analysis similar to the one that compares owners with renters.

We start off by defining the main explanatory variables used in this study (for all variable definitions, see Appendix A). These variables include a mix of income related, socio-economic, demographic and geographic variables that traditionally are considered to be important determinants of homeownership and the housing finance decision.

The existing literature identifies household income as an important determinant of homeownership (Linneman and Wachter (1989)) and housing finance (Hendershott and Pryce (2006)). We define the variable INCOME as the combined gross income of all household members adjusted for the number of household members using the

as part of the national housing policy. Taxation on owner occupied housing assets is done through the calculation of an estimated rental value of $1.25 \%$ of the value of the house minus mortgage interest, making investment in real estate (financed by mortgage debt) for owner occupancy more attractive relative to other assets. For a detailed discussion of the taxation scheme in the Netherlands, see Cnossen and Bovenberg (2001), and Rele and van Steen (2001). 
Eurostat equivalence scale. ${ }^{18}$ As the maximum mortgage loan advanced by lenders is often a multiple of household income, income therefore determines whether (and how much) the household receives mortgage debt in the first place. Moreover, at the time of initiating the mortgage a higher income to house value ratio implies a stronger potential to pay off the house purchased. This allows households to adopt a higher initial LTV. While this positive effect may be mitigated by high income households having a higher capacity to repay debt more quickly, we would expect the effect of the higher initial LTV to dominate.

To capture household wealth, we introduce NETWORTH, which is the difference between the net worth and the estimated house price appreciation since its purchase. All else equal wealthier households have the choice between converting their net worth into liquid assets to finance the house or, alternatively, to keep (or spend) those assets and to finance the house by debt. Households with little net worth, on the other hand, have no other option but to finance the house by debt. Wealth constraints may therefore induce a negative relation between net worth and the LTV.

We separately introduce the variable BENEFIT, previously not used in the literature. This variable comprises unemployment, sickness and disability benefits adjusted for the number of household members using the Eurostat equivalence scale. While social benefits are a source of income, they also signal that the household may be experiencing difficulties (such as unemployment, incapacities or illness) that could adversely affect homeownership propensity. The effect of benefits on the financing decision is therefore ambiguous. On the one hand, while benefits are a source of income, lenders may categorize it as 'low quality' income against which it may be more difficult to borrow. Moreover, households are less likely to own a house. Very often, on the other hand, households may become recipients of benefits after they have taken out a mortgage (as result of redundancy or accidents). In that case the household's capacity to service the debt may, ex post, be substantially diminished making it more difficult to reduce LTV. BENEFIT is expected to have an overall positive marginal effect on LTV.

\footnotetext{
${ }^{18}$ We use income values that are adjusted for the number of household members, as this gives a better measure of the relative earnings position of the household. The equivalence is computed using the Eurostat scale, which considers the first household member with a factor 1 , the second 0.5 , and any additional member 0.3. The equivalence values are then equal to per capita values where the number of household members is calculated according to the relevant scale. For a detailed discussion of this and other used income equivalence scales see OECD (2006b).
} 
$T A X$ is defined as the estimated effective tax rate equal to the ratio of the tax bill (the difference between the gross and net income) and the tax base (the difference between the gross income and the estimated mortgage interest). Households with a higher tax rate also have a higher potential tax shield. Interest on mortgage debt is tax deductible (whereas rent is not). Furthermore, capital gains on the household's residence are tax exempt. The tax deductability of mortgage interest should increase the expected outstanding mortgage debt. Furthermore, theory predicts (see Henderson and Ioannides (1983)) that a higher, more progressive tax rate stimulates homeownership because there is a bigger financial advantage from owning versus renting. The positive effect of taxation on homeownership should further strengthen this positive relation. The existing literature (e.g. Hendershott and Pryce (2006)) argues that taxes may have an effect on outstanding LTV. All else equal, a household with a higher tax bill has a higher potential tax shield and may want to adopt more debt over its life cycle. Variable $T A X$ captures the estimated effective tax rate faced by a household and is predicted to have a positive relation with $L T V$.

We define D_MEM2 and D_MEM3 as dummy variables taking the value of 1 for households with exactly two and at least three members, respectively, and zero otherwise. We expect that $D_{-} M E M 2$ and $D_{-} M E M 3$, as well as $A G E$, the age of the oldest household member expressed in years, positively affect both the probability of homeownership as well as LTV (the later being a result of a preference towards ceteris paribus a bigger, thus more expensive, house). As retired households sometimes move into homes for the elderly or convert the equity in their home into cash for consumption, the relation between the probability of homeownership and $A G E$ may, however, be nonmonotonic. $D_{-} E D U$ is a dummy variable taking value of 1 for tertiary or vocational education and zero otherwise. The effect of this variable (if any) remains an open question. Furthermore, we introduce $D_{-} U R B L$, a dummy variable equal to 1 if the household lives in an area with a low degree of urbanization and 0 otherwise. ${ }^{19}$

$A F F$ measures affordability and is defined as the ratio of the average income in the province of household $i$ in year $t$ (as reported by the CBS and standardized for the

\footnotetext{
${ }^{19}$ The Central Bureau of Statistics (CBS) in the Netherlands uses a measure of address density in a particular area to measure the degree of urbanization. The degree of urbanization is expressed in 5 categories going from 'very high' degree of urbanization (code 1) with a density of more than 2,500 addresses per square kilometer, to a 'very low' degree of urbanization (code 5) with less than 500 addresses per square kilometer. The same convention is used in our data - the degree of urbanization takes on the discrete values between 1 and 5, covering the spectrum from 'very high' to 'very low'. Our dummy variable $D \_U R B L$ equals one for urbanization levels 3 to 5 , and zero otherwise.
} 
number of household members) to the average value of the house in that province (as reported by the Dutch land registry office). $R C O$ captures the (inverse) relative cost of ownership and is defined as the ratio of the average rent to the average house value in the province of household $i$ in year $t$. TY PE represents the type of dwelling, and is equal to 1 for a single family home, 2 for appartment/flat, and 3 for all other cases (such as shared accommodation).

Finally, INT denotes the difference between the mortgage interest rate of household $i$ and the prevailing market interest rate in year $t$.

We now first explore whether renters are inherently different from homeowners in terms of their characteristics. To test the null hypothesis that both samples (i.e., renters and homeowners) are drawn from populations with the same distribution (the same mean) for the various characteristics, we use the Mann-Whitney test (the t-test). We find overwhelming evidence against the null hypothesis over the whole sample period for pretty much all household variables considered. ${ }^{20}$ This shows that the characteristics of renters and homeowners are fundamentally different. Using a t-test for the equality of means, we find that homeowners exhibit higher average net worth (€103, 527 for owners compared to $€ 21,608$ for renters), enjoy higher income (€25, 033 versus $€ 17,630$ ), are more highly educated (0.67 versus 0.57 ), are subject to a higher average tax rate (0.30 versus 0.25$)$, have higher affordability ratio (0.12 versus 0.11$)$. Homeowners also receive lower social benefits than renters (€966 versus $€ 1,659$ ). On the demographical side, home-owning households are larger on average (eg. $45 \%$ have 3 or more family members, whereas the corresponding percentage for renters is $24 \%$ ). Homeowners also live in less highly urbanized areas (with an average of 0.66 for the urbanization dummy variable for owners and 0.44 for renters) and enjoy bigger houses (a house type indicator equal to 1.20 and 1.54 for owners and renters, respectively). All these differences are significant at the $1 \%$ level. The analysis of subsamples corresponding to the first and the last sample periods indicates that the qualitative differences between homeowners and renters prevail over time as most of the differences that are significant in the initial period (period 1) are significant in the final period (period 4) and also over the entire sample period. ${ }^{21}$

[Insert Table 6 about here]

\footnotetext{
${ }^{20}$ Exceptions are the variables $A F F, D \_M E M 2$ and $A G E$ for which the null hypothesis cannot be rejected in every sample period.

${ }^{21}$ Again, the exceptions are $A F F, D \_M E M 2$ and $A G E$, for which the difference is not always significant.
} 
The second key question we address in this section relates to the type of mortgage financing that homeowners are using. In particular, we compare the holders of repayment mortgages with those who opted for a non-repayment mortgage. Table 7 compares the characteristics of repayment mortgageholders and non-repayment mortgageholders over the total sample period, for period 1 and for period 4 (1992-1995 and 2003-2005, respectively).

Focussing on period 1 first, the Mann-Whitney test provides strong evidence that both sub-samples are very different with respect to most explanatory variables (except for the degree of urbanization, and the relative cost of owning versus renting). The t-tests for the means provides evidence that in the first period more flexible nonrepayment mortgages are chosen by households with higher income (€30,653 versus $€ 26,426$ for owners with a repayment mortgage), which are more highly educated (0.71 versus 0.66$)$ and subject to a higher tax rate ( 0.35 versus 0.34$)$. In addition, nonrepayment mortgage holders are younger (46.08 years versus 49.24 years), live in bigger houses (1.15 versus 1.25$)$, which are more affordable ( 0.15 versus 0.14$)$, have lower (inverse) relative cost of ownership (2.8 versus 2.82$)$ and receive less social benefits ( $€ 753$ versus $€ 1,303)$. Moreover, non-repayment mortgages are associated with higher markups on market interest rates (2.38 versus 1.86$)$. All the differences are significant at a $1 \%$ significance level for the means as well as distributions (apart from $R C O$, for which the difference in means is significant at the $5 \%$ level and the difference in distributions is not significant). These results suggest that the more financially "sophisticated" households (cf. Campbell (2006)) tend to choose the more flexible, though more expensive, non-repayment mortgage to optimize dynamically their financing structure. ${ }^{22}$ Consequently, the evidence obtained so far indicates the higher LTV associated with non-repayment mortgages does not necessarily translate into higher risk.

This picture changes quite dramatically in the final period where the distributional differences between the two groups are no longer statistically significant (even at a 10\% significance level) for important variables such as income $(I N C)$, affordability $(A F F)$, the type of housing (TYPE), the (inverse) relative cost of ownership $(R C O)$ and the degree of urbanization $\left(D_{-} U R B L\right)$. Furthermore, households choosing non-repayment mortgages are now on average less highly educated (0.69 and 0.77), contrary to the situation observed in the initial sample period. Their tax rate is higher only at $10 \%$

\footnotetext{
${ }^{22}$ The lower net worth of the households choosing flexible mortgages (€82,729 and $€ 89,705$ ) is not inconsistent with this view as by choosing non-compulsory repayment mortgages and deferring payments, they avoid the need of reducing today's consumption.
} 
significance level and benefits are lower at a $5 \%$ level. Finally, the differences in age and net worth retain the same sign and similar statistical significance.

The univariate analysis of the two groups of borrowers indicates that initially more flexible, non-repayment contracts are selected mainly by financially sophisticated households, who do not face particular financing constraints (as their incomes are on average higher) but who are willing to optimize dynamically their financing structure (to maximize the utility of their lifetime consumption by, e.g., deferring repayments and minimizing the tax liability). However, towards the end of the sample period the differences in the characteristics of households diminish or even disappear. The loss of the discriminatory power of the key variables indicates that non-repayment mortgages have to a large extent substituted compulsory repayment contracts through the entry of below-average quality households to the group of flexible borrowers. As a consequence, the riskiness of mortgage pool has increased and the higher LTV ratios of flexible mortgage holders are likely to reflect financing constraints and not necessarily the optimizing behavior with respect to the financing structure.

The results for the whole sample period provide a mixed picture for the obvious reason that the composition of the pool of borrowers choosing non-repayment mortgages changes over time, as we just explained. The comparison of the two groups of borrowers across the entire sample period reveals that households with non-repayment mortgages have generally lower net worth, lower age, are subject to a lower tax rate, live in a more highly urbanized areas, but also in bigger houses, while enjoying higher income and lower social benefits (see Table 7).

[Insert Table 7 about here]

Our previous conclusions with respect to the increased riskiness of non-repayment mortgages over time are based on the implicit assumption that non-repayment mortgages exhibit a higher LTV ratio. In fact, this assumption is supported by the data. A comparison of the average LTV ratios across the two major types of mortgage contracts indicates a growing gap between LTVs of non-repayment and repayment contracts over the sample period. In particular, the average gap in years 2003-2005 (period 4) equals $0.52-0.25=0.27$, and exceeds the corresponding value for years 1992-1995 (period 1$)$ amounting to $0.59-0.43=0.16$. 


\section{Regression analysis}

We model empirically the following economic problem. Each household can make an irreversible decision to buy a house. ${ }^{23}$ The decision is only going to be made if a latent variable (a function of a number of economic, demographic and geographical variables) exceeds a certain level. As we are not able to observe the entire history of each household (nor have an exact economic model for the value of the latent variable), the ownership regression is aimed at explaining the maximum historical propensity to own a house using a household's current characteristics. Financing decisions are assumed to be made continuously, in the sense that a household can freely choose the level of leverage at each point throughout its house tenure. However, the type of mortgage financing is selected only once - when the (first) mortgage is initiated. Furthermore, any contractual restrictions on the level of leverage for compulsory repayment mortgages, which are inherent to this type of financing products, are viewed as just one of the factors contributing to the level of leverage (and are captured by a dummy characterizing the mortgage type).

Define $O W N^{*}$ to be the variable corresponding to the (unobserved) historical maximum of the propensity to own a house, with $O W N^{*}>0$ equivalent to a household finding it optimal to buy their home at some point in the past. $L T V^{*}$ is the current borrowing propensity and reflects the desired loan-to-value ratio. We are interested in estimating the following relationships:

$$
\left\{\begin{array}{l}
O W N_{i t}^{*}=X_{1 i t} \alpha+\varepsilon_{i t} \\
L T V_{i t}^{*}=X_{2 i t} \beta+\eta_{i t},
\end{array}\right.
$$

where $X_{j i t}, j \in\{1,2\}$ is a vector of explanatory variables, parameters $\alpha$ and $\beta$ denote vectors of model coefficients and $\varepsilon_{i t}\left(\zeta_{i t}\right)$ is the error term drawn from a bivariate normal distribution with mean 0 and variance $\sigma_{\varepsilon}^{2}\left(\sigma_{\zeta}^{2}\right)$. The covariance between both error terms is $\sigma_{12}$, which can be different from zero. Subscripts $i$ and $t$ correspond to a household and a year, respectively.

As $O W N^{*}$ and $L T V^{*}$ describe preferences, which are not observable, we define two new variables:

\footnotetext{
${ }^{23}$ In our sample, only 105 households, i.e., $2 \%$ of total number of households decided to reverse the decision and moved to a rented property. Moreover, there are 335 cases of households changing their mortgage type.
} 


$$
O W N_{i t} \equiv\left\{\begin{array}{lll}
1 & \text { if } & O W N_{i t}^{*}>0 \\
0 & \text { if } & O W N_{i t}^{*} \leq 0
\end{array}\right.
$$

and

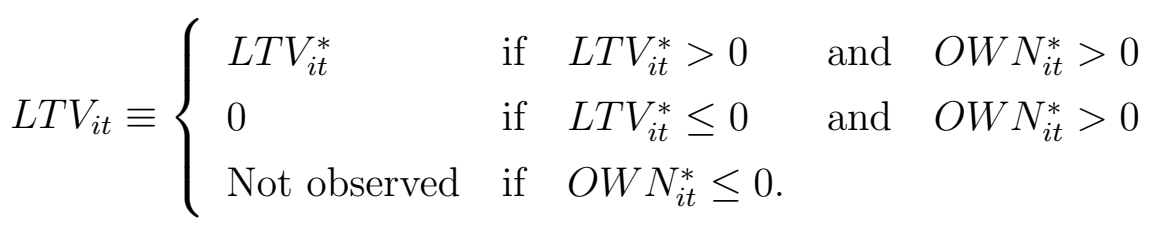

Consequently, $O W N$ is a binary variable describing homeownership and $L T V$ is the current loan-to-value ratio of a household that owns a home (therefore, $L T V$ is only observed in the group of owners).

In the described model, only the sign of $O W N^{*}$ is observed and $L T V$ is observed only when $O W N_{i t}^{*}>0$. The vector of explanatory variables, $X_{1 i t}$, is observed for all data points and $X_{2 i t}$ may not be known for those observations for which $O W N^{*}$ (or even $L T V^{*}$ ) is negative. The first equation in (1) is the selection equation as it corresponds to the household's self-selection into the group of homeowners. The second equation is the regression equation.

We analyze the ratio of the outstanding mortgage loan to the value (LTV) for households that have selected to own a property and decide to borrow a strictly positive amount. The modeling approach that most closely reflects the spirit of a household's decision problem is a double-hurdle regression model (Cragg (1971)). The model allows for the absence of borrowing to be a result of $i$ ) the absence of homeownership, or $i i$ ) the decision to finance the property entirely with equity. As data requirements for the double-hurdle model are the most stringent, we also estimate Heckman sample selection (cf. Amemiya (1984), see also Li and Prabhala (2006)) and OLS models with a richer set of explanatory variables.

The double-hurdle specification is the one consistent with the system of equations (2) and (3) but it requires that the vectors of explanatory variables $\left(X_{1}\right.$ and $\left.X_{2}\right)$ be observed for the entire sample. As some of the explanatory variables of interest (e.g., mortgage type) are not observed for a fraction of observations (renters), the double-hurdle model can be estimated only with a subset of explanatory variables. To circumvent this limitation, we also estimate the Heckman sample selection model, which does not require that $X_{2}$ be observed for those households that do not self-select to the group of owners. The disadvantage of using Heckman specification is that it assumes that the explained variable in the regression equation $(L T V)$ is always positive if the 
household belongs to the group of owners. ${ }^{24}$ As such, it ignores the second possibility in equation (3), that is, that homeowners adopt a $100 \%$ equity financing. To make sure that our conclusions are not affected by the exclusion of the group of owners which are non-borrowers, we estimate a tobit model using the subsample of owners. While ignoring sample selection issues (by not taking account the third possibility in (3)), such a specification allows for including homeowners with no outstanding mortgage debt. Unfortunately, the tobit specification also requires that $X_{2}$ be observed also for those households who do not borrow, which puts similar restriction on the feasible set of explanatory variables as the double-hurdle model. Therefore, we also estimate a conditional OLS model of LTV for households that select to borrow a strictly positive amount. This model allows us to use the full set of the explanatory variables and does not require making specific assumptions about the reason for the exclusion from the group of the borrowers (negative propensity to borrow or non-participation in the housing market). ${ }^{25}$

The interpretation of the regression parameters and the corresponding marginal effects depends on the exact model specification. For the double-hurdle, Heckman and tobit models, it reflects the effect of the exogenous variable on the (unobserved) propensity to borrow. For the OLS model, it reflects the corresponding effect on the observed LTV conditional on the household having a mortgage loan outstanding. To see the differences between the estimated coefficients, consider the following example. Assume that household income affects positively both the propensity to own a house and the propensity to borrow and that the corresponding regression error terms, which represent unobserved factors affecting the propensities, are positively correlated. Regression coefficients of the double-hurdle, Heckman and tobit models will be the estimates of the true parameter $\beta_{i n c}$. However, the coefficient of the OLS model reflects the effect of income conditional on the selection to the sample of borrowers. In the analyzed example, the conditional marginal effect is smaller than $\beta_{i n c}$. This is due to the fact that ceteris paribus the expected LTV is higher if the household is included among the owners, which is the result of a positive correlation between the two error terms. If

\footnotetext{
${ }^{24}$ In our sample, this assumption is violated for 1,562 observations, for which homeownership is not associated with the presence of mortgage financing. As a result, those observations are omitted when the Heckman model is estimated.

${ }^{25}$ As the OLS estimator based on a model with truncated data is generally biased when sample selection is not random, see Greene (2000), pp. 902-903, we also calculate the conditional marginal effects based on the sample selection model. The estimated effects (available upon request) are in line with those obtained for the OLS model.
} 
the level of the explanatory variable increases, the magnitude of the shock needed for the household to be included in the group of owners becomes smaller. As a smaller (positive) error term in the selection equation is associated with a smaller expected error in the LTV equation, the increase of the expected LTV (conditional on selection to the group of borrowers) following the marginal change in income is lower than the true model coefficient. ${ }^{26}$

Finally, in the second part of the analysis, we define the following variable to investigate the choice of mortgage category:

$D_{-} N R P M T_{i t} \equiv \begin{cases}1 & \text { if } \quad N R P M T_{i t}^{*}>0 \text { and } \min \left\{L T V_{i t}^{*}, O W N_{i t}^{*}\right\}>0 \\ 0 & \text { if } \quad N R P M T_{i t}^{*} \leq 0 \text { and } \min \left\{L T V_{i t}^{*}, O W N_{i t}^{*}\right\}>0 \\ \text { Not observed } & \text { if } \min \left\{L T V_{i t}^{*}, O W N_{i t}^{*}\right\} \leq 0,\end{cases}$

$D_{-} N R P M T$ is therefore a dummy variable equal to 1 if a household has a noncompulsory repayment mortgage and 0 otherwise, and $N R P M T^{*}$ denotes the (unobserved) propensity to select a non-compulsory repayment mortgage. Model (4) is estimated using the sample selection probit (Heckman probit) approach. The model is therefore based on the same principle as the standard Heckman model with the only difference being that the explained variable in the regression model is binary (here mortgage category). The selection equation in the estimated Heckman probit is the same as the selection equation of model (1). ${ }^{27}$

\section{$5.1 \quad$ Results}

We begin with the results of the simple model of LTV, which is formulated as follows

\footnotetext{
${ }^{26}$ The effect in tobit model will be affected in the same way as in the Heckman and double-hurdle models with positively (negatively) correlated error terms and identical (opposite) signs of the coefficients of the relevant variable in the selection and regression equation. In such a case, the conditional effects will be of a smaller absolute value. If in a Heckman or a double-hurdle model the positively (negatively) correlated error terms are combined with opposite (identical) signs of the coefficients in the selection and regression equation, then the conditional marginal effect will (in absolute terms) be greater.

${ }^{27}$ To estimate model (4) using Heckman probit with selection equations as in (1), we essentially assume that the sign of $L T V_{i t}^{*}$ and $O W N_{i t}^{*}$ is the same for each pair $(i, t)$. See also footnote 24 .
} 


$$
\begin{aligned}
L T V_{i t}^{*}= & \beta_{0}+\beta_{1} S Q R T \_I N C_{i t}+\beta_{2} S Q R T \_N E T W O R T H_{i t}+\beta_{3} S Q R T \_B E N E F I T_{i t} \\
& +\beta_{4} T A X_{i t}+\beta_{5} T A X_{i t} * D_{-} A F T 97+\beta_{6} D \_M E M 2_{i t}+\beta_{7} D_{-} M E M 3_{i t} \\
& +\beta_{8} A G E_{i t}+\beta_{9} A G E_{i t}^{2}+\beta_{10} D_{-} E D U_{i t}+\beta_{11} Y E A R_{i t}+\beta_{12} D \_U R B L_{i t}+\eta_{i t} .
\end{aligned}
$$

Recall that the propensity to borrow, $L T V^{*}$, is defined as the (desired) ratio of the current value of the mortgage outstanding and the market value of the house. When implementing model (5), we use $L T V$, given by (3), as $L T V^{*}$ is generally not observable. ${ }^{28}$ The choice of most of the explanatory variables has been motivated in Section 4. In addition, SQRT_INC,SQRT_NETWORTH and SQRT_BENEFIT are introduced and denote square-root transformations of INC, NETWORTH and $B E N E F I T$, respectively. ${ }^{29}$ To capture the possible effect of the tax regime shift we also introduce the interaction dummy D_AFT97 that equals 1 for period 1998-2005, and zero otherwise. Variable $Y E A R$ corresponds to the year number and is defined as the actual year number minus 1992. This variable should capture a possible time trend in household leverage that results from factors that cannot be controlled for, such as governmental policies (aimed, e.g., at promoting homeownership), proliferation of mortgage products or, more generally, changes in credit market conditions.

It is important to stress that we are not modeling the household's initial (i.e., at mortgage commencement) loan-to-value, but the outstanding loan-to-value at the time of the survey. It is more challenging (and more general) to model the latter than the former. For example, while the former is primarily determined by lending policies and borrowers' financing constraints, the latter is also affected by household life-cycle effects, past income and liquidity shocks. As such the possible variation in outstanding LTV is typically much larger than the variation in initial LTV. Obviously, initial LTV is a special case of outstanding LTV (if households are surveyed immediately after mortgage commencement, then the outstanding LTV coincides with the initial LTV).

[Insert Table 8 about here]

\footnotetext{
${ }^{28}$ We performed a robustness check of the reliability of the reported house values by estimating model (5) for subsamples with varying maximum time since mortgage commencement. We did so to verify whether there is any systematic bias in reported house values that may increase with the time elapsed since house purchase. We found that our results are not particularly sensitive to the choice of the maximum time since mortgage commencement allowed in the sample.

${ }^{29}$ The square root is a commonly used transformation in demographics research (see Goodman (1988)) to adjust for positive skewness in variables.
} 
The results of the LTV regression model (5) are reported in Table 8 and generally confirm hypothesis $\mathrm{H} 1$ about the relevance of socio-economic variables. The sign of the relationship between $L T V$ and income is positive and significant for all model specification. Depending on the specification, an increase of income by $€ 10,000$ translates for the average borrowing household (with income $€ 25,350$ ) into an expected increase in LTV ratio between 0.025 and 0.039 (depending on the model specification). The positive relation indicates a higher debt capacity of high-income households. Net worth $(N E T W O R T H)$ has a strong negative effect on outstanding LTV: less wealthy households have no other choice but to take on more debt. An increase of $€ 10,000$ reduces expected leverage by 1-2 percentage points for the mean borrowing household, which has a net worth of $€ 84,797$. Social benefits increase LTV - the estimate of the net economic effect of an extra euro of social benefits on LTV ranges between 3 and 9 percentage points. The amount of taxes paid has a significantly positive (prior to 1997) but economically rather modest effect on LTV. A $1 \%$ increase in the effective tax rate leads to an increase in LTV by $0.16-0.20$ percentage points. The relationship loses its statistical significance after 1997, that is, when tax relief on interest is phased out, except for interest on mortgage debt.

Leverage increases with the number of household members. A second member adds on average between 0.017 and 0.085 to LTV, which is slightly lower than the estimated effect of any higher number of members (between 0.023 and 0.112). The marginal effect of age varies (based on Model 1 in Table 8) from -0.012 for $A G E=20$ to -0.008 for $A G E=40$ and -0.005 for $A G E=60$. Education positively influences the propensity to borrow (the estimates range from 0.013 to 0.023 ) and significantly affects the observed LTV (as indicated by p-value in the conditional OLS model). The estimate of the effect of calendar time ranges from 0.26 to 0.57 percentage points per year. This time effect reflects the autonomous change in the levels of household leverage that can be attributed to the changes in regulation and in the level of credit supply.

Finally, the negative coefficient of the low-level urbanization dummy (which ranges from not significant to -0.034) indicates that the level of urbanization may positively influence the observed LTV ratio. This result is consistent with housing in more urbanized areas being less affordable and, as such, requiring a higher proportion of debt financing.

The estimated parameters of the sample selection equation (Table 8, Panel B) are in line with the analysis of the determinants of homeownership in Section 4 and, to a large extent, with the literature (see, e.g., Goodman (1988), Zorn (1989), Jones 
(1989), Haurin, Hendershott, and Wachter (1997) and Coulson (2002)). Namely, the probability of homeownership is positively affected by income, net worth, education, and the estimated tax rate. Furthermore, consistent with the results of the univariate analysis, households having more members and who live in larger homes situated in less highly urbanized areas are more likely to belong to the group of owners. Contrary to the results of Section 4, social benefits do not seem to be a statistically significant determinant of homeownership. Also, the coefficient of affordability has a negative sign (this result may to same extent capture the non-linearity of the time trend).

Having analyzed the model of choice based on a basic set of explanatory variables, we proceed to a richer specification that takes into account the characteristics of the outstanding mortgage contracts. Our descriptive statistics indicate that the type of mortgage financing chosen (payment versus non-repayment mortgages) may have a persistent, long-term effect on the evolution of LTV. The mortgage type is fixed when the mortgage is initiated and, as such, an exogenous variable. We denote the mortgage type by the dummy variable $D_{-} N R P M T$ (where $D_{-} N R P M T=1$ for non-repayment mortgages, and zero otherwise). ${ }^{30}$

We predict that the choice of mortgage type determines the effect of income on the outstanding LTV. While income positively affects the initial LTV level, for nonrepayment mortgages this effect is likely to be higher for the following reasons. The possibility of deferring the repayment of the principal implies that non-repayment mortgages support a higher initial LTV ratio. Moreover, the resulting higher interest payment allows for more significant tax deductions.

Furthermore, the time elapsed since mortgage commencement (which we denote by MTGTIME) certainly effects LTV. Households, unlike firms, have a natural, finite lifetime. The income generating power of households is limited in time, and therefore also its capacity to service debt. It seems therefore unrealistic to impose the assumption that households maintain some inter-temporal optimal LTV ratio. This is the main motivation for introducing the variable MTGTIME in the regression, as well as $M T G T I M E^{2}$, to allow for non-linearities.

We allow the marginal effect of income to depend on MTGTIME, the time elapsed since mortgage commencement (to capture life-cycle effects), and also on D_NRPMT,

\footnotetext{
${ }^{30} \mathrm{It}$ is worth pointing out that since the late nineties it has become easier and relatively cheaper for households to remortgage and therefore to change the mortgage type. Still, among 7,860 borroweryears, there are only 335 occurrences of a mortgage type change. Those changes are usually associated with an increase of the level of debt.
} 
the mortgage repayment type (to capture the degree of discretion in repaying the mortgage principal). More specifically, we introduce the following regressors $I N C V$, INVC*MTGTIME, INCV*MTGTIME ${ }^{2}, I N C V * D \_N R P M T, I N C V * M T G T I M E *$ $D \_N R P M T$ and $I N C V * M T G T I M E^{2} * D_{-} N R P M T$. The quadratic term corresponding to the time since mortgage commencement allows for possible non-linearities. $I N C V$ denotes the ratio of gross income adjusted for the number of household members (using the Eurostat scale) and exclusive of social benefits and the value of the house. Another new variable, BENEFITV, equals the ratio of BENEFIT and the house value. ${ }^{31}$

The inclusion of the extra variables comes at a cost - we are no longer able to estimate tobit and double-hurdle models as they require the availability of the same set of explanatory variables for both uncensored and censored groups of observations. Therefore, we start our analysis with the conditional OLS regression specification and subsequently estimate the Heckman sample selection model. As described before, the coefficients (and marginal effects) of the OLS model are conditional on the LTV being observed and positive, whereas the coefficients of the sample selection model reflects the sensitivities of the unobserved propensity to borrow, $L T V^{*}$.

\section{[Insert Table 9 about here]}

The results of the two types of the extended version of the LTV regression model (5) are consistent across the model variants and are reported in Table 9. The sign of the relationship between $L T V$ and income depends on the mortgage category. For compulsory repayment contracts, each euro of additional income translates into 33 cents of additional borrowing for the average time since mortgage commencement $(\bar{T}=$ 12.33). ${ }^{32}$ For non-compulsory repayment contracts, each euro of additional income translates into a 39 cent increase in the borrowing level. As the marginal effect for the repayment mortgages does not decrease with time, the positive relation indicates a higher debt capacity of high-income households. A generally higher sensitivity of LTV to income of non-repayment mortgages reflects the fact that a given level of income can support higher leverage if the repayment of the principal can be delayed.

\footnotetext{
${ }^{31}$ Income and benefits are scaled by the value of the house as it is the size of the income relative to the house value that actually matters. This scaling is similar in spirit to capital structure models for firm leverage that scale the exogenous variables by the assets of the firm.

${ }^{32}$ In the remainder of the section, we report the sensitivities based on the conditional OLS model unless stated otherwise.
} 
A somewhat less obvious result is that the marginal effect of income on LTV varies over the lifetime of the mortgages. As previously pointed out, the behavior of the marginal effect of income is quite different for repayment and non-repayment mortgages. With repayment mortgages the (positive) marginal effect on LTV is fairly stable (it equals 0.142 for $T=0,0.348$ for $T=15$ and 0.271 for $T=30$ ). Income positively affects the initial LTV level only, as subsequent repayment behavior is determined by the compulsory repayment schedule. Unlike repayment mortgages, for non-repayment contracts the marginal effect of income on LTV is monotonic and increasing over the lifecycle of the mortgage ( 0.216 for $T=0,0.424$ for $T=15$ and 0.573 for $T=30$ ). Positive income shocks lead to an increase in LTV. Furthermore, this positive relation strengthens over time, which reflects a bigger dispersion of LTV across households as the time increases. Towards the end of the mortgage term $(T=30)$ each euro of additional income leads to an increase of about 57 cents of mortgage debt.

Our analysis confirms that net worth (NETWORTH) has a negative effect on outstanding LTV. According to the estimate of the marginal effect for Model 1 (Table 9 ), an increase in net worth amounting to $€ 10,000$ reduces expected leverage by 1.18 percentage points for the average household.

Social benefits increase LTV for both types of mortgages. For households on repayment mortgages, the estimates of the net economic effect of an extra euro of social benefits on outstanding mortgage debt range between 40 and 52 cents. The estimates of the analogous effect for households on non-repayment contracts range between statistically not significant and 20 cents. (Still, the difference is significant at most at the $10 \%$ level.)

The amount of taxes paid has a statistically significantly positive (at least prior to 1997) effect on LTV. A one-percentage point increase in the effective tax rate leads to an increase in LTV of 0.15 to 0.25 percentage points. The relationship loses its statistical significance after 1997, that is, when tax relief on interest is phased out, except for interest on mortgage debt.

In the extended specification, we are now able to quantify also the direct effect of the time elapsed from the origination of the mortgage, MTGTIME. The signs of the coefficients for time to mortgage commencement and the same variable squared indicate that LTV is a convex decreasing function of time. Furthermore, we include interaction terms of MTGTIME with income and mortgage category variables. Every year elapsed from the origination of the mortgage reduces the loan-to-value ratio on average (i.e., for the average income and the time since mortgage commencement) 
by $1.32 \%$ for repayment mortgages and by $1.40 \%$ non-repayment contracts. The decreasing trend is easily explained by the fact that house values tend to go up, whereas the outstanding mortgage tends to go down over time. More surprising is the finding that this time trend for repayment mortgages (taken in isolation) is statistically not distinguishable from that for non-repayment contracts since the coefficient of variable MTGTIME*D_NRPMT (time to mortgage commencement multiplied by the mortgage category dummy) is not significant. This does, however, not mean that the time pattern of LTV is the same for both mortgage types. As mentioned earlier, the marginal effect of income on LTV over the household's life cycle is different for the two types of mortgages. Note also that the dummy variable for non-repayment mortgages is positive and highly significant. The regression coefficient indicates that (after controlling for all other effects) the outstanding LTV for non-repayment mortgages is more than $11 \%$ percentage points higher than for repayment mortgages!

As we have already shown in Table 8, leverage increases with the number of household members. The estimates obtained for the coefficient of $D_{-} M E M 2$ range between 0.014 and 0.061 , whereas the marginal effect of D_MEM2 lies between 0.045 and 0.113 . The coefficient of $E D U$ varies from statistically not significant (the conditional OLS model) to 0.015 (Heckman model of propensity). The estimated coefficient of calendar time $(Y E A R)$ range from 0.004 to 0.005. Again, as shown in Table 8, the estimated coefficient of the low-level urbanization dummy ranges between statistically not significant and -0.024 , which may suggest that housing in more urbanized areas is less affordable and requires a higher proportion of debt financing.

The above LTV regression leads to the important finding that outstanding LTV is significantly higher for households that have a non-repayment mortgage than for households with a repayment mortgage. This result holds after adjusting the explained variable for the cash value of life insurances accumulated in investment vehicles that are linked to non-repayment mortgages. The regression lumps, however, the various non-repayment mortgage types in one basked by using a dummy that merely differentiates non-repayment mortgages from repayment mortgages, without considering the particular type of non-repayment mortgage. Since the features of non-repayment mortgages can be quite different across types, one may wonder whether the above result holds for each of the individual types of non-repayment mortgage. We therefore extend the analysis to allow for the dependence of the financing structure on the mortgage type (Models 2 and 4 in Table 9 ). The newly introduced dummy variable $D_{-} M T G k$ corresponds to mortgage type $k$, where 2 corresponds to the traditional life insurance 
mortgage, 3 - improved life insurance mortgage, 4 - linear mortgage, 5 - endowment mortgage, and 6 - other (such as the interest only mortgage). The benchmark type of mortgage is the annuity mortgage, which together with the linear mortgage (type 4) constitutes the set of the compulsory repayment mortgages.

The dummy variable of the linear (repayment) mortgage (type 4) is insignificant making the LTV of this mortgage type similar to the one of annuity (repayment) mortgages (the benchmark mortgage type). The dummy variables of all non-repayment mortgages are positive and range in Model 2 from 0.032 to 0.146 (from 0.019 to 0.146 in Model 4). (Although one of the non-repayment type dummies are not significant at $10 \%$, all four are jointly significant at $1 \%$ as indicated by the likelihood ratio test.) If we consider the average household (by evaluating the regressors at their sample average) then the expected LTVs for the average household are 0.378, 0.506, 0.461, 0.323, 0.391 and 0.461 depending on whether it has adopted a mortgage of type 1 to 6 , respectively.

It follows that the LTV ratio is expected to be the lowest for the annuity and linear mortgages. This result is consistent with the fact that these mortgage types are associated with compulsory annual repayment. Conversely, households financed with mortgages which do not include a compulsory repayment component are expected to exhibit higher LTV ratios, which are ceteris paribus up to almost 15 percentage points higher than the benchmark level corresponding to the annuity mortgage.

As expected (cf. hypothesis H2), the predicted LTV ratio for an average household with a non-repayment mortgage exceeds that of an analogous household with a compulsory repayment contract. The predicted difference of about 10 percentage points does not vary much with the time elapsed. For instance, the average LTV ratio for non-repayment mortgages exceeds its repayment counterpart by 0.124 for $T=0$, by 0.099 for $T=15$ and by 0.116 for $T=30) .{ }^{33}$

To investigate what causes the proliferation of non-repayment mortgages, we estimate conditional and Heckman sample selection probit models that explain the probability of selecting the more innovative, non-repayment mortgage products (Table 10). As with the analysis of LTV, homeownership is the sample selection criterion.

We use the same set of explanatory variables for the regression equation as in the

\footnotetext{
${ }^{33}$ As a robustness check (available upon request), we estimate our model after subtracting the cash value of the investment vehicle linked to non-repayment mortgages scaled by house value, from the numerator of $L T V$. These tax efficient investments comprise, for example, life insurances. Since these investments are a substitute for paying off the mortgage principal, the described deduction is made to capture the net level of the loan.
} 
model of LTV augmented with house affordability, $A F F$, but without the mortgage types - which the current model aims at explaining - and mortgage duration:

$$
\begin{aligned}
N R P M T_{i t}^{*}= & \gamma_{0}+\gamma_{1} I N C V_{i t}+\gamma_{2} S Q R T \_N E T W O R T H_{i t}+\gamma_{3} B E N E F I T V_{i t} \\
& +\gamma_{4} T A X_{i t}+\gamma_{5} T A X_{i t} * D_{-} A F T 97+\gamma_{6} D_{-} M E M 2_{i t}+\gamma_{7} D \_M E M 3_{i t} \\
& +\gamma_{8} A G E_{i t}+\gamma_{9} A G E_{i t}^{2}+\gamma_{10} D_{-} E D U_{i t}+\gamma_{11} Y E A R_{i t}+\gamma_{12} D \_U R B L_{i t} \\
& +\gamma_{13} A F F_{i t}+\zeta_{i t} .
\end{aligned}
$$

$N R P M T^{*}$ is the latent variable describing the propensity to take a non-repayment mortgage (its observable counterpart is the dummy $D_{-} N R P M T$ ) and $\zeta_{i t}$ is the error term. The negative marginal effect of income indicates that non-repayment mortgages are more likely to be generally selected by less affluent households. A decrease in the ratio of income-to-house value by ten percentage points reduces the probability of having the non-repayment contract by 0.010 . The effect of NETWORTH, which measures financial wealth of a household (and the presence of funds) is statistically highly significant. An increase of NETWORTH by $€ 10,000$ reduces the probability of a household selecting a non-repayment mortgage by 0.003 . The latter two results indicate that the selection of more flexible contracts is a response of households to financial constraints resulting from an increasing wedge between house prices and income. The negative relation between net worth and the probability of selecting a non-repayment mortgage may also result from the consumption-smoothing role of flexible contracts. Namely, households may find it optimal to maintain a desired level of consumption by deferring the repayment of the principal. As a result of such a behavior, net worth will ceteris paribus be lower.

\section{[Insert Table 10 about here]}

Surprisingly, the probability of selecting a flexible mortgage diminishes with the amount of received social benefits. The effect on the probability of selecting the nonrepayment contract of increasing the ratio of social benefits to house value by ten percentage points is -0.066 .

The proliferation of non-repayment mortgages has often been attributed to tax incentives. There is clear evidence that tax advantages of non-repayment mortgages are responsible for the wave of remortgaging around the turn of the century (Ministry of 
Housing (2002b)). By providing greater flexibility in timing the repayment of the outstanding mortgage principal, non-repayment mortgages allow income to be sheltered more effectively against taxes by using the tax deductibility of mortgage interest payments. Instead of paying off the mortgage, contributions towards the future repayment of the principal are being deposited into a separate tax efficient investment vehicle. As predicted, the amount of taxes paid has a positive effect on the likelihood of a nonrepayment mortgage being selected. A 1 percentage point increase in the effective tax rate leads to an increase in the probability of selecting the non-repayment mortgage of 0.004. (The changes in the tax code occurring after 1997 do not significantly affect this coefficient.)

The probability of selecting a non-repayment mortgage is also higher for bigger households and for those that have a higher level of education (however, the latter effect is not statistically significant at the $10 \%$ level). The effect of age on the mortgage type dummy is negative, which indicates that these are usually younger households who opt for the more flexible form of mortgage financing. For $A G E=20$, an incremental year is associated with an 0.017 reduction in the probability of selecting a non-repayment mortgage. The corresponding marginal effect diminishes over time and equals -0.010 and -0.004 for $A G E=40$ and $A G E=60$, respectively. The marginal effect of $D_{-} M E M 2$ equals 0.106 , whereas that of $D_{-} M E M 3$ amounts to 0.113 . Finally, the marginal effect of $D \_E D U$ equals 0.021 .

The marginal effects of the basic version of the model clearly indicate that calendar time plays a significant role in explaining the probability of selecting non-compulsory repayment mortgage contracts. For the mean household in the owners sub-sample, the probability of selecting the more flexible mortgage contract increases by 0.028 for an incremental year. Variable $Y E A R$ is significant at the $1 \%$ level, which indicates that there is an accompanying autonomous shift towards more flexible products over time, which is independent from another variable related to time, house affordability. Since the effect of calendar time is still present after controlling for demographic, financial, urbanization, and house affordability indicators, we attribute it to the wider availability of the more flexible mortgage products. ${ }^{34}$

The negative marginal effect of the low-level urbanization dummy, -0.016 , is (again) not statistically significant but its sign is consistent with the view that housing in more urbanized areas is less affordable and, as such, associated with more flexible mortgage

\footnotetext{
${ }^{34}$ The lack of statistical significance of the marginal effect of $D_{-} P E R 4$, equal to 0.142 , may reflect the fact that $A F F$ captures the effect of time trend, which is omitted from the Models 2 and 4.
} 
types. Finally, the negative coefficient of $A F F$ suggests that lower house affordability induces households to select more flexible contracts. (The marginal effect translates into a 0.102 increase in probability of selecting a non-repayment contract for a reduction in the affordability index by 0.1 , however, due to a large standard error, the coefficient is not statistically significant at the $10 \%$ level.)

The dynamic aspect of the effect of economic, demographic and location variables on the choice of mortgage is captured by estimating the probability model separately for the initial (1992-1995) and the final (2003-2005) period of the sample. The outcome of the regression model largely supports the results of the univariate analysis (see Section 4 ) - it is the more financially sophisticated households that initially adopt flexible mortgage contracts to optimize their dynamic financial structure and likely exposure to taxes. In the initial period, the probability of selecting a non-repayment contract is positively related to education, tax rate, affordability as well as to the number of household members and negatively related to the amount of social benefits received and age (see Table 11). The results based on period 1992-1995 support therefore hypothesis H3a.

\section{[Insert Table 11 about here]}

The results of the empirical analysis differ dramatically if we consider the final period. Most of the variables lose their statistical significance, apart from age and benefits (the significance of the latter is at the 10\% level). Furthermore, gross income and net worth are now negatively related (at the $10 \%$ level) to the probability of being financed with a flexible mortgage. Again, those results suggest that towards the end of the sample period these are no longer predominantly financially sophisticated households that select non-standard products. Instead, those products are at least equally likely to be selected by less well-off, likely financially constrained households. For those households, flexible mortgages offer the possibility of deferring the repayment of the mortgage principal, and may be the only feasible way of financing the purchase of a house. As a consequence, the recently observed proliferation of the non-repayment mortgages, which also contributes to the higher levels of LTV, reflects the substitution of traditional products by new, flexible mortgages (cf. hypothesis H3b). As such, it signals the deterioration of the average quality of mortgage loans relative to a decade ago. ${ }^{35}$

\footnotetext{
${ }^{35}$ The results reported in Table 11 are to a large extent corroborated by our findings concerning
} 
So far, we have not addressed the question of a potentially higher marginal cost of borrowing more and selecting a non-repayment contract. According to hypothesis $\mathrm{H} 4$, interest rates that households face increase with LTV and are higher when the non-repayment feature is present. If, on the contrary, non-repayment contracts were not more expensive than the standard, compulsory repayment mortgages, no rational household would optimally select the latter and their market share would systematically decrease. ${ }^{36}$

There are two potential issues that need to be taken into account when analyzing the effect of LTV and of the mortgage type on the cost of financing. First, the interest rates vary over time as a result of the monetary policy of the central bank and such fluctuations are not associated with changing household characteristics. Therefore, we use variable $I N T$, which is defined as the difference between the mortgage interest rate and the interest rate set by the central bank. Second, both the LTV ratio as well the mortgage type are likely to be determined jointly with the mortgage interest rate. Consequently, it is a prori not obvious whether a simple regression of the interest rate on the LTV (or, on the mortgage type) is going to pick households' demand curve, lenders' supply curve or some combination of both (Working (1927), see also Binsbergen, Graham, and Yang (2009)). To circumvent this problem, we use the twostage regression approach, under which the predicted values of household $L T V$ are used instead of the actual values. In a similar spirit, we use a treatment regression when modeling the effect of the mortgage type, which is a binary variable, on the interest rate. $^{37}$

[Insert Table 12 about here]

The results of the analysis are presented in Table 12. LTV is shown to positively affect the interest rate level although the magnitude of the effect is surprisingly small.

the determinants of LTV across the two periods (available from the authors upon request). Income and education have smaller or no influence on LTV in period 2003-2005 compared with the significant positive effects in 1992-1995, whereas non-compulsory repayment mortgages are associated with, on average, much higher LTV ratios (the coefficient of dummy D_NRPMT increases from 0.09 in 1992 1995 to 0.19 in 2003-2005).

${ }^{36}$ Obviously, when allowing for deviations from full rationality, some households may be expected to choose those contracts as a measure of restricting consumption to pay off debt within the stipulated horizon.

${ }^{37}$ The first stage equation for $L T V$ and the selection equation for $D \_N R P M T$ follow specifications (5) and (6), respectively. 
For each additional 10 percentage points of the LTV ratio, the interest rate increases by a mere 0.1 percentage points. Moreover, the interest rate decreases with income (by 0.16 percentage points for each $€ 10,000$ of income), household size, education and social benefits ( 0.31 percentage points for each $€ 10,000$ of benefits, despite the fact that benefits are often regarded as a "less pledgeable" source of income). Using the treatment regression, we show that the interest rate is positively related to the flexibility embedded in the mortgage contract. Other things being equal, non-repayment mortgages are associated with interest rates that are, on average, 3.55 percentage points higher than the rates of the compulsory repayment contracts. ${ }^{38}$ Finally, we analyze whether there are any changes in the cost of flexibility embedded in non-repayment contracts between periods 1992-1995 and 2003-2005. The results of our test indicate that flexible contracts become much less costly towards the end of the sample period than at the beginning. Between 1992 and 1995 the mark-up on the borrowing cost associated with the flexible contract amounts to 3.54 percentage points, whereas it is not statistically significant in period 2003-2005. The proliferation of non-repayment contracts may therefore be at least partially attributed to their declining cost. ${ }^{39}$

\section{Conclusions}

This paper analyzes housing finance patterns of Dutch households for the period 19922005. We estimate a model for the LTV of households that have outstanding mortgage debt and find strong evidence of life-cycle effects. LTV declines with the time elapsed since mortgage commencement. Income positively affects the initial LTV level for repayment mortgages. Subsequent income shocks positively affect the level of debt, irrespective of the time since mortgage commencement. Households with little net worth, higher marginal tax rates and a larger number of family members tend to have a higher LTV. After controlling for all the above factors we find that the outstanding LTVs of non-repayment mortgages are still on average $10 \%$ higher than for repayment mortgages.

Our results also indicate that non-repayment mortgages substitute the repayment

\footnotetext{
${ }^{38}$ The magnitudes and signs of coefficients of variables explaining the mortgage type are in line with those reported in Table 10.

${ }^{39}$ Although statistical significance of the predicted value of $M T G \_T Y P E$ is likely to be negatively affected by the relatively small predictive power of regressors in the mortgage type model estimated for years 2003-2005, we did not find a positive relationship between MTG_TYPE and INT in a regression in which the actual value of $M T G \_T Y P E$ was used.
} 
contracts by gradually replacing them in the marketplace. The proportion of nonrepayment mortgages has increased from $58 \%$ in 1992 to $88 \%$ in 2005 . To find out what may drive this trend, we estimate a probit model that has as the dependent variable the probability of a household choosing a non-repayment mortgage (as opposed to a repayment mortgage). We find that households with a higher marginal tax rate, lower net worth, a lower income to house value and more household members are more likely to have a non-repayment mortgage. This confirms the widely held belief that non-repayment mortgages are chosen because of the tax advantages they confer.

Furthermore, following the initial period in which mostly wealthy and financially sophisticated households chose non-repayment mortgages, we observe a shift towards flexible contracts among less well-off families. This is partially attributed to a declining mark-up on the interest rate charged on the non-repayment mortgages. The growing share of less well-off households among non-repayment mortgage holders indicates that it is declining house affordability and the resulting financing constraints that have contributed to the proliferation of non-repayment mortgages. We therefore conclude that over the last decade the riskiness of the total pool of mortgage contracts has increased. 


\section{A Definition of variables}

All monetary items are translated into 1994 units. $^{40}$

House value - current value of the accommodation $(b 26 o g b)$, right-truncated at $2 \mathrm{~m}$. $O W N$ - dummy variable equal to 1 if a household owns a house and zero otherwise. $I N C$ - Eurostat-adjusted gross income (btot) minus benefits $(w g+w w+z w+r w w+$ $a a w+w a o+i o a w)$, left-truncated at 0 .

NETWORTH - difference between the net worth (totasset - totdebt) left-censored at zero and the estimated house price appreciation. The house price appreciation is calculated as the difference between the current house value and the purchase price house (b26ogb - wo34) (with observations corresponding to house purchases before 1950 truncated).

BENEFIT - Eurostat-adjusted unemployment, sickness and disability benefits ( $w g+$ $w w+z w+r w w+a a w+w a o+i o a w)$.

$T A X$ - estimated effective tax rate defined as the ratio of the tax bill (the difference between the gross and net income) and the tax base (the difference between the gross income and the estimated mortgage interest) right-truncated at 1.

D_AFT97 - dummy variable equal to 1 for observations from period 1998-2005 and zero otherwise.

$D \_M E M 2$ - dummy variable equal to 1 if a household consists of (exactly) 2 members and zero otherwise.

D_MEM3 - dummy variable equal to 1 if a household consists of at least 3 members and zero otherwise.

$A G E$ - age of the oldest household member expressed in years, right-truncated at 100 . $D \_E D U$ - dummy variable equal to 1 for tertiary or vocational education and zero otherwise.

$Y E A R$ - actual year number minus 1992.

D_PERn, $n \in\{2,3,4\}$ - dummy variable equal to 1 in period 1996-98 ( $n=2), 1999-02$ $(n=3)$, and 2003-05 $(n=4)$, respectively, and to zero otherwise.

$D \_U R B L$ - dummy variable equal to 1 for (low) urbanization levels 3-5 and zero otherwise (see footnote 19).

$R C O$ - (inverse) relative cost of ownership, is constructed using our household sample and is defined as the ratio of the average rent to the average house value in the province of household $i$ in year $t$.

\footnotetext{
${ }^{40}$ To avoid ambiguity, for some variables we provide original codes used in the survey.
} 
TYPE - dwelling type (1 - a single family house/duplex, 2 - flat, 3 - other).

$A F F$ - ratio of the average income in the province of household $i$ in year $t$ (as reported by the CBS and standardized for the number of household members) to the average value of the house in that province (as reported by the Dutch land registry office).

$S Q R T \_I N C$ - square-root transformation of $I N C$.

SQRT_NETWORTH - square-root transformation of NETWORTH.

SQRT_BENEFIT - square-root transformation of BENEFIT.

$I N C V$ - ratio of $I N C$ and the house value, left-truncated at 0.

$B E N E F I T V$ - ratio of BENEFIT and the house value.

$L T V$ - ratio of the value of the loan outstanding $(b 26 h y b)$ and the house value, righttruncated at 1.5 .

MTGTIME - time since mortgage commencement defined as the maximum of the time since the current mortgage start (year - hyp61) and the time spent in a current accommodation (year - wo5).

$D \_M T G k, k \in\{2,3,4,5,6\}$ - dummy variable equal to 1 for the traditional life insurance mortgage $(k=2)$, improved life insurance mortgage $(k=3)$, linear mortgage $(k=4)$, endowment mortgage $(k=5)$, and other types - such as the interest only mortgage $(k=6)$, respectively.

$D_{-} N R P M T$ - dummy variable equal to 1 for non-compulsory repayment mortgage contracts $(k=2,3,5$, or 6$)$ and 0 otherwise.

$I N T$ - difference between the mortgage interest rate and the prevailing market interest rate. 


\section{B Mortgage types}

Description of mortgage types: ${ }^{41}$

ANNUITY MORTGAGE: with an annuity mortgage, the total amount of your periodic payments on interest and repayment remains the same (at least) during the period for which the interest rate was fixed. During the first part of this period, the amount due consists of a relatively large part of interest and a relatively small part of repayment. In later years, it is the other way around.

TRADITIONAL LIFE-INSURANCE MORTGAGE: this sort of mortgage consists of a loan and a life insurance policy. The idea is that there is no repayment, but only paying interest on the loan, and paying a premium for the life-insurance policy. There is no direct relation between the interest rate of the mortgage loan and the savings interest rate of the life-insurance policy (in contrast with an improved life-insurance mortgage, where there is a relation between those two interest rates).

IMPROVED LIFE-INSURANCE MORTGAGE: this is a modernized version of a traditional life insurance mortgage. An improved life-insurance mortgage consists of a loan and a life-insurance policy. The idea is that there is no repayment, but only paying interest on the loan, and paying a premium for the life-insurance policy. In this case, the interest rate of the mortgage-loan and the savings interest rate of the life-insurance policy are related, which causes monthly net-costs to be rather stable.

LINEAR MORTGAGE: with this sort of mortgage, the periodic payments include paying off a fixed percentage of the total mortgage loan, and paying interest on the loan that is left at that moment. Over time, the amount you pay on interest becomes less and less, such that total monthly costs go down through the years. In the first period of the term of the mortgage, the costs of a linear mortgage are higher than the costs of an annuity mortgage.

ENDOWMENT MORTGAGE: with an endowment mortgage it is possible, during the term of the mortgage, to get a new loan on (part of) the amount that you have already paid off.

\footnotetext{
${ }^{41}$ The mortgage types description in this section is a direct translation (by CentERdata) of the notes in the questionnaire presented to the inquired households.
} 
INVESTMENT MORTGAGE: this is a new variation on the (traditional) life-insurance mortgage. As is the case with the other life-insurance mortgages, also for most of the investment mortgages the loan is paid off out of the benefits of a whole life-insurance policy linked to the mortgage at the end of the mortgage period. Contrary to a(n improved) life-insurance mortgage, the returns of the life-insurance policy are based on the returns of an investment portfolio.

INTEREST ONLY: With this mortgage one only pays interest during the term of the mortgage with a balloon payment due at the end.

ANNUITY CONSTRUCTION: During the term of the mortgage one pays interest only, but at the same time one contributes to an annuity, which becomes available at the end of the mortgage period. The annuity does not have to be used to pay off the mortgage at the end of the mortgage period. It can be used as a supplementary pension provision.

LIFE-INSURANCE: the lifelong mortgage with life-insurance is a variation on the interest only mortgage. This mortgage is taken out for an indefinite period. To be sure that the mortgage is paid off after death (at the latest), the mortgage holds a term life-insurance policy. 


\section{References}

Alessie, R., S. Hochguertel, and A. van Soest (2002): "Household Portfolios in the Netherlands," in Household Portfolios, ed. by L. Guiso, M. Haliassos, and T. Jappelli. MIT Press.

Amemiya, T. (1984): "Tobit models; A survey," Journal of Econometrics, 24, 3-61.

Binsbergen, J. H. V., J. Graham, And J. Yang (2009): "The Cost of Debt," Stanford GSB Working Paper.

Brounen, D., and P. Neuteboom (2006): "Demography and Housing Demand Dutch Cohort Evidence," Erasmus University Working Paper.

Brounen, D., P. Neuteboom, and A. van Dijkhuizen (2006): "House Prices and Affordability - A First and Second Look Across Countries," DNB Working Paper.

Bucks, B., And K. Pence (2006): "Do Homeowners Know Their House Values and Mortgage Terms?," FED Board of Governors Working paper.

Campbell, J. Y. (2006): "Household Finance," Journal of Finance, 61(4), 15531604, Presidential Adress to the American Finance Association.

Case, K. E. (2000): "Real Estate and the Macroeconomy," Brookings Papers on Economic Activity, 2, 119-145.

Charlier, E., and A. van Bussel (2003): "Prepayment Behavior of Dutch Mortgagors: An Empirical Analysis," Real Estate Economics, 31(2), 165-204.

Cnossen, S., And L. Bovenberg (2001): "Fundamental Tax Reform in The Netherlands," International Tax and Public Finance, 8(4), 471-484.

Coulson, N. E. (2002): "Regional and State Variation in Homeownership Rates; Pennsylvania's Would its Ownership Rate be as High?," Journal of Real Estate Finance and Economics, 24(3), 261-276.

Cragg, J. G. (1971): "Some Statistical Models for Limited Dependent Variables with Application to the Demand for Durable Goods," Econometrica, 39(5), 829-844.

Demyanyk, Y., and O. Van Hemert (2008): "Understanding the Subprime Mortgage Crisis," Review of Financial Studies, forthcoming. 
Englund, P., P. Hendershott, and B. Turner (1996): "Loan-to-value ratios in Sweden - The impact of financial deregulation," Scandinavian Housing and Planning Research, 13(3), 113-127.

Follain, J. R. (1990): "Mortgage Choice," AREUEA Journal, 18(2), 125-144.

Goodman, A. C. (1988): "An Econometric Model of Housing Price, Permanent Income, Tenure Choice, and Housing Demand," Journal of Urban Economics, 23, $327-353$.

Greene, W. H. (2000): Econometric Analysis. Prentice Hall.

Guiso, L., M. Haliassos, And T. Jappelli (2002): Household Portfolios. MiT Press.

Guiso, L., P. Sapienza, And L. Zingales (2008): "Trusting the Stock Market," Journal of Finance, 63, 2557-2600.

Haurin, D. R., P. H. Hendershott, and S. M. Wachter (1997): "Borrowing Constraints and the Tenure Choice of Young Households," Journal of Housing Research, 8(2), 137-154.

Hendershott, P. H., And G. Pryce (2006): "The sensitivity of homeowner leverage to the deductibility of home mortgage interest," Journal of Urban Economics, $60,50-68$.

Henderson, J., And Y. Ioannides (1983): "A Model of Housing Tenure Choice," American Economic Review, 73, 98113.

Jones, L. (1989): "Current Wealth and Tenure Choice," AREUEA Journal, 17(1), $17-40$.

Koijen, R., O. Van Hemert, and S. van Nieuwerburgh (2008): "Mortgage Timing," Journal of Financial Economics, forthcoming.

Li, K., and N. Prabhala (2006): "Self-Selection Models in Corporate Finance," in Handbook of Corporate Finance: Empirical Corporate Finance, ed. by B. E. Eckbo, chap. 2. Elsevier/North Holland.

LI, W. (2005): "Moving Up: Trends in Homeownership and Mortgage Indebtedness," Business Review - Federal Reserve Bank of Philadelphia, Q1, 26-34. 
Linneman, P., and S. Wachter (1989): "The Impacts of Borrowing Constraints on Homeownership," AREUEA Journal, 17(4), 389-402.

Ministry of Housing (2002): "Home Ownership in the Netherlands," Discussion paper, - Department of Spatial Planning and the Environment.

OECD (2004): "OECD Economic Survey of the Netherlands 2004: Housing Policies," Discussion paper, - OECD Economic Surveys.

_ (2006a): "Owning Up," OECD Observer, 255.

(2006b): "What are Equivalence Scales?," Discussion paper, - OECD Social Policy Division.

Rele, H., And G. Van Steen (2001): "Housing Subsidisation in the Netherlands: Measuring its Distortionary and Distributional Effects," Discussion paper, - CPB Discussion Paper, N.2.

Von Furstenberg, G. M. (1969): "Default Risk on FHA-Insured Home Mortgages as a Function of the Terms of Financing: A Quantitative Analysis," Journal of Finance, 24(3), 459-477.

Working, E. J. (1927): "What Do Statistical "Demand Curves" Show?," The Quarterly Journal of Economics, 41(2), 212-235.

Zorn, P. (1989): "Mobility-Tenure Decisions and Financial Credit: Do Mortgage Qualification Requirements Constrain Homeownership?," AREUEA Journal, 17(1), $1-16$. 
Figure 1: Households Number, Housing Stock, House Price Index, Interest Rate and House Affordability

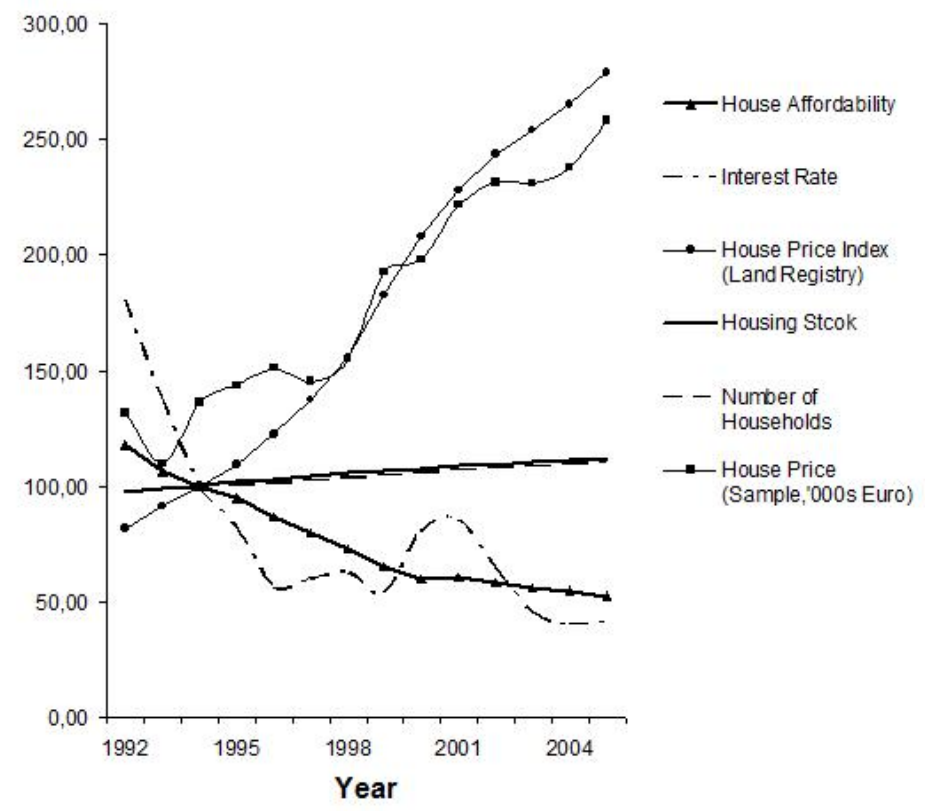

The evolution of the Housing Stock, Number of Households, House Price Index (HPI), House Affordability, and Interest Rates. Values presented are relative to year 1994 where all variables equal 100, except for average sample house prices, which are expressed in thousands of euro. Total Dutch Housing Stock in 1994 is 6.192 million houses. Total number of households in the Netherlands in 1994 is 6.445 million. The $H P I_{1994}$ (Land Registry) equals 100, and the average house value for our sample in year 1994 is 136 thousand euro. House Affordability is measured as the ratio of an index measure of standardized income (which equals 100 in 1994) and the House Price Index. The interest rate variable is presented as an index with value 100 for year 1994, and refers to the Guilder Market Interest Rate until 1999, and the Eurozone thereafter. The guilder interest rate for year 1994 is 5.14\%. (Data Sources: Statistics Netherlands (CBS), Dutch Land Registry Office, and DNB Household Survey.) 
Figure 2: Number of Household Members and Loan to Value Histograms

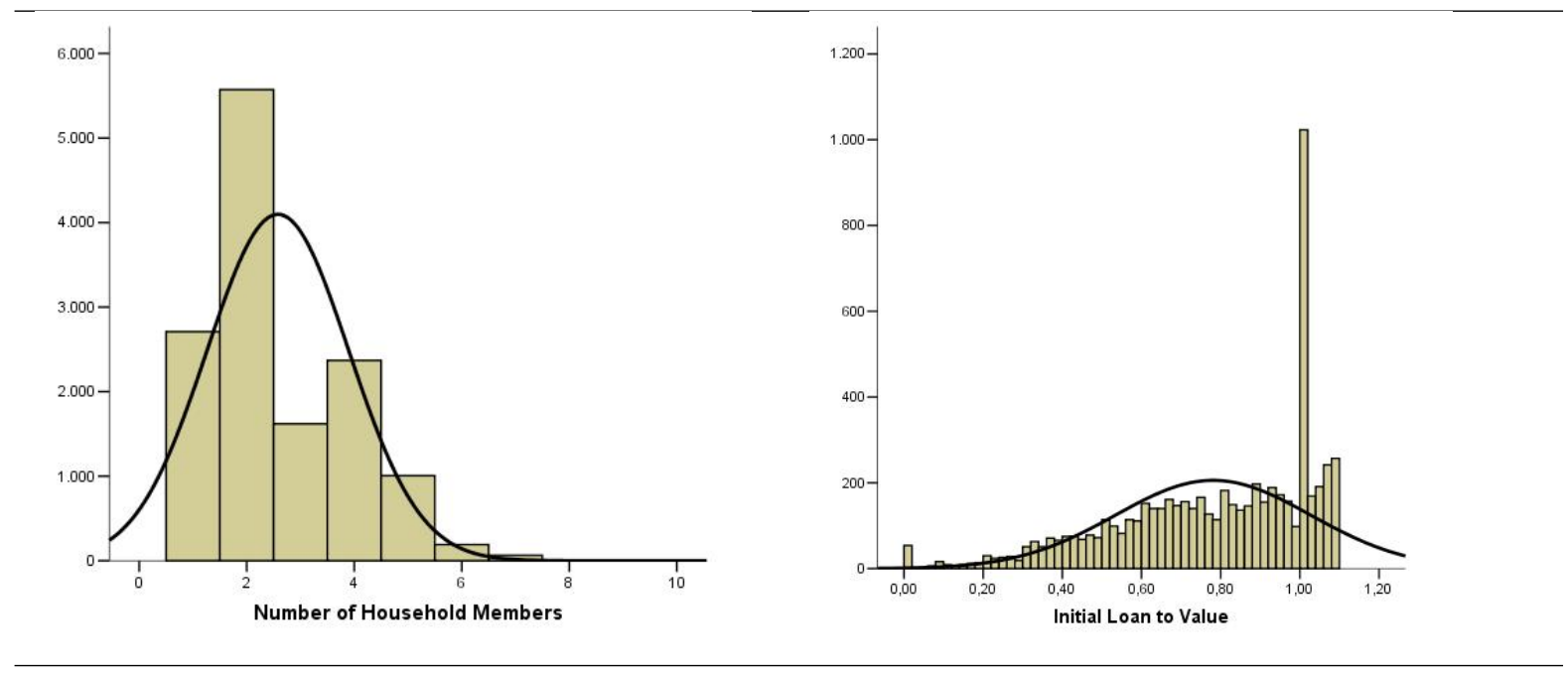

Panel C: Loan to Value (All Homeowners)

Panel D: Loan to Value (Mortgage Holders)

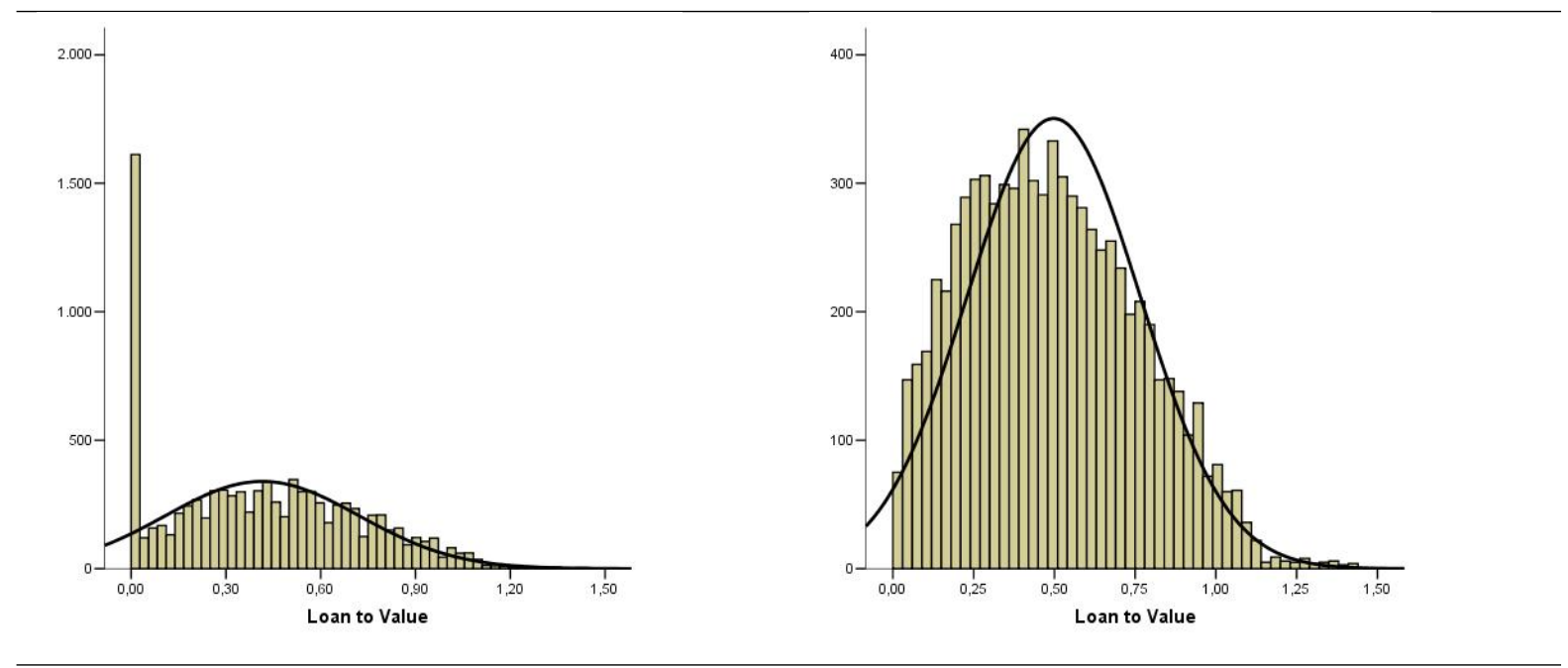

Histograms for the number of household members and mortgage loan to values. Panel A presents the histogram of the distribution of households considering the number of household members for the full sample of households. Average number of members is 2.58, with standard deviation 1.32. Total number of observations in Panel A is 13,546. Panel B presents the histogram of the distribution of households considering the initial mortgage loan to house value for the full sample of households. Average initial loan to value is 0.781 , with standard deviation 0.246. Total number of observations in Panel B is 6,351. Households considered in Panel B are only those reporting initial loan to value between 0.10 and 1.10 , in order to remove outliers originating in the usage of different units to measure initial loan and initial house values in the sample. Panel C presents the histogram of the distribution of households considering mortgage loan to value at the moment of response to the questionnaire. All owner households are considered in Panel C. Average loan to value for all owner households is 0.415, with standard deviation 0.307. Total number of observations in Panel C is 9,422. Panel D presents the histogram of the distribution of households considering mortgage loan to value at the moment of response to the questionnaire. Only mortgaged households are considered in Panel D, and average loan to value is 0.497 , with standard deviation 0.270. Total number of observations in Panel D is 7,860 . 


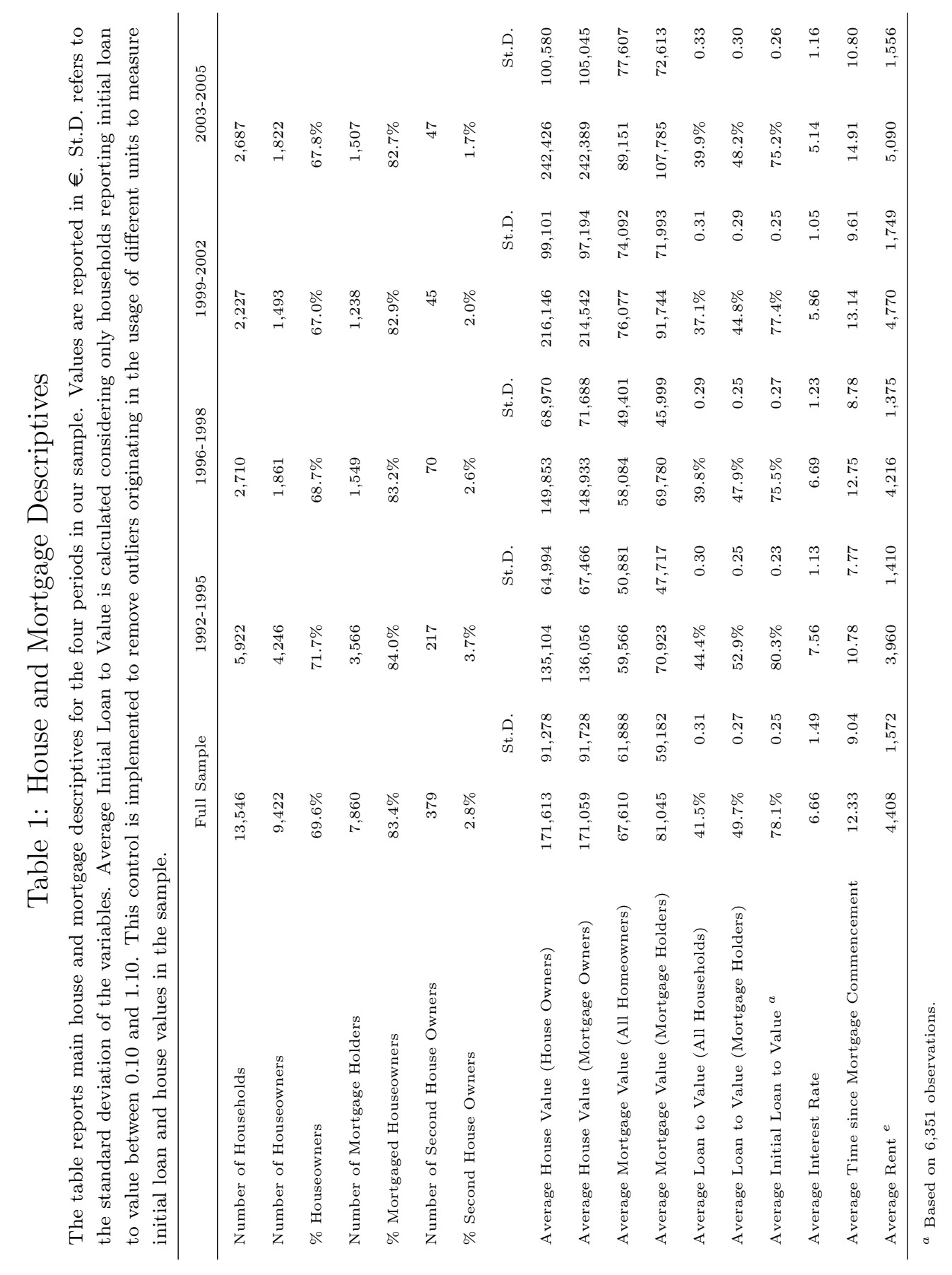




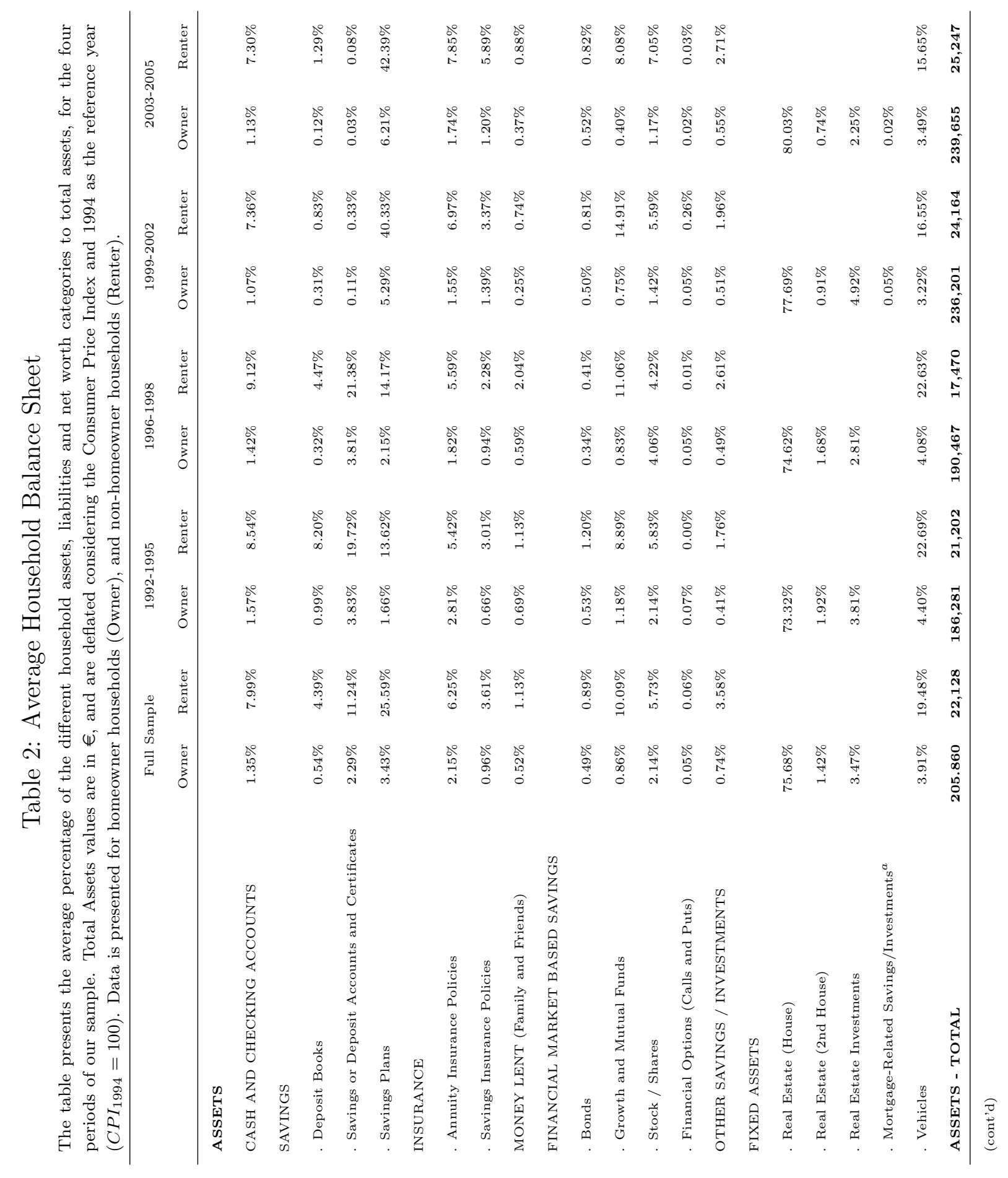




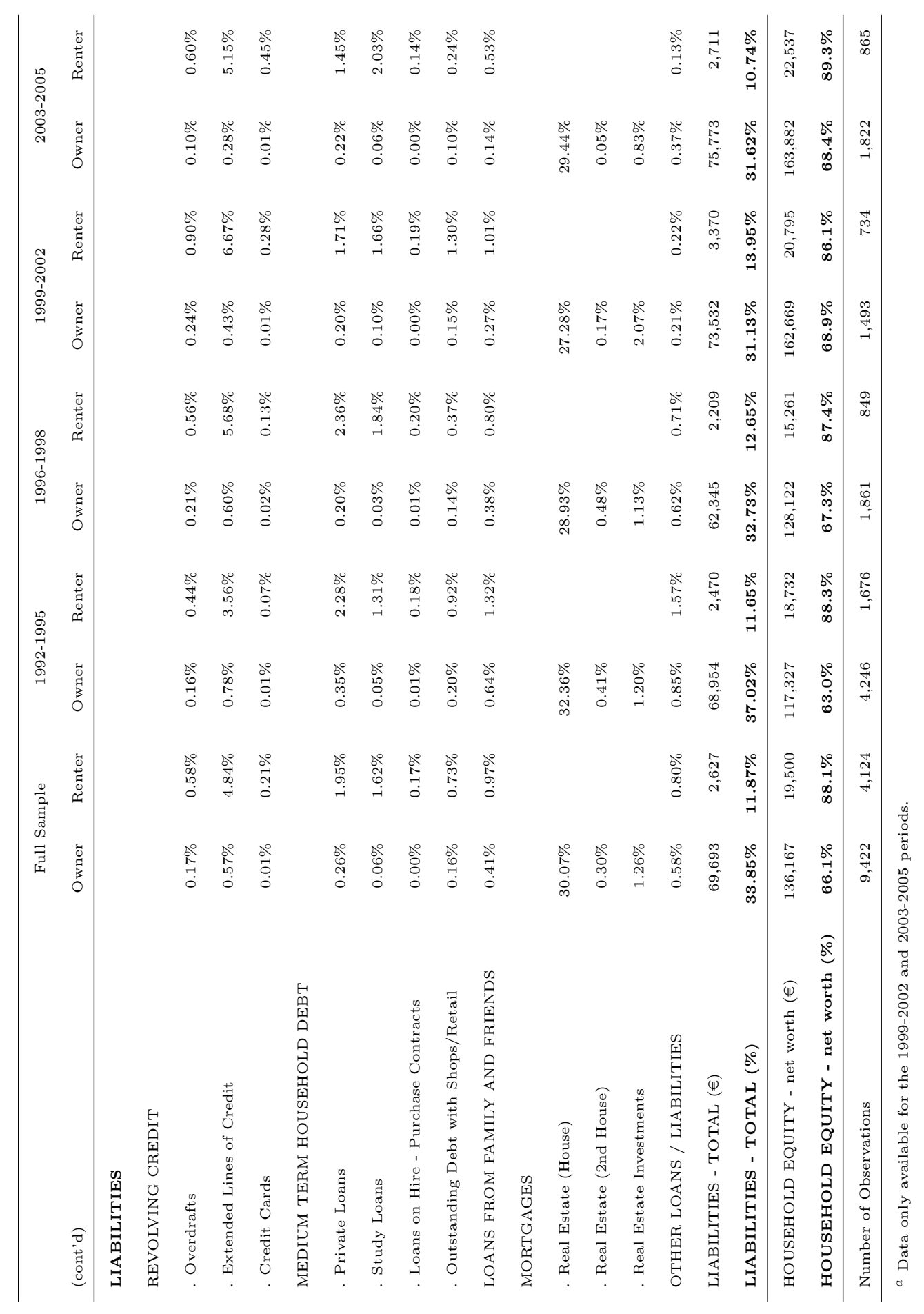




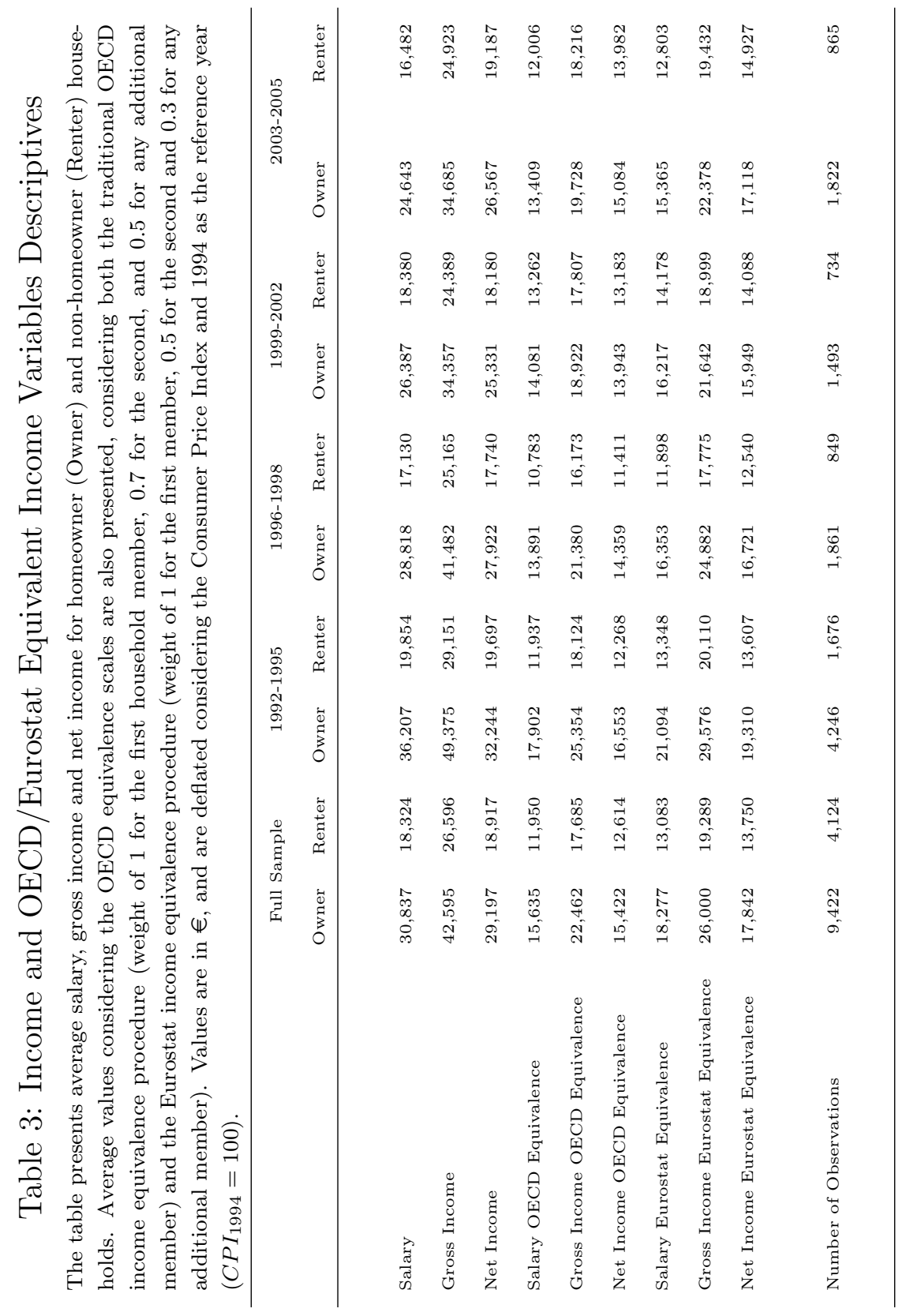




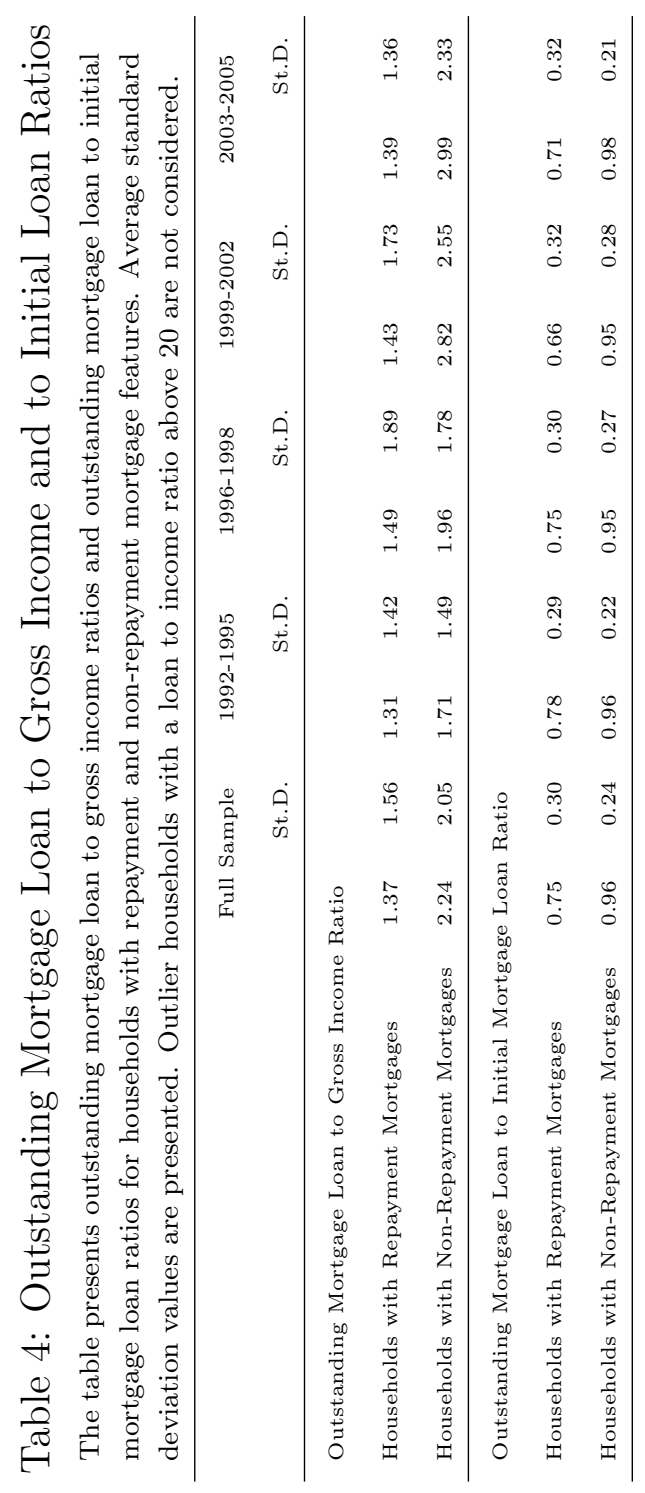




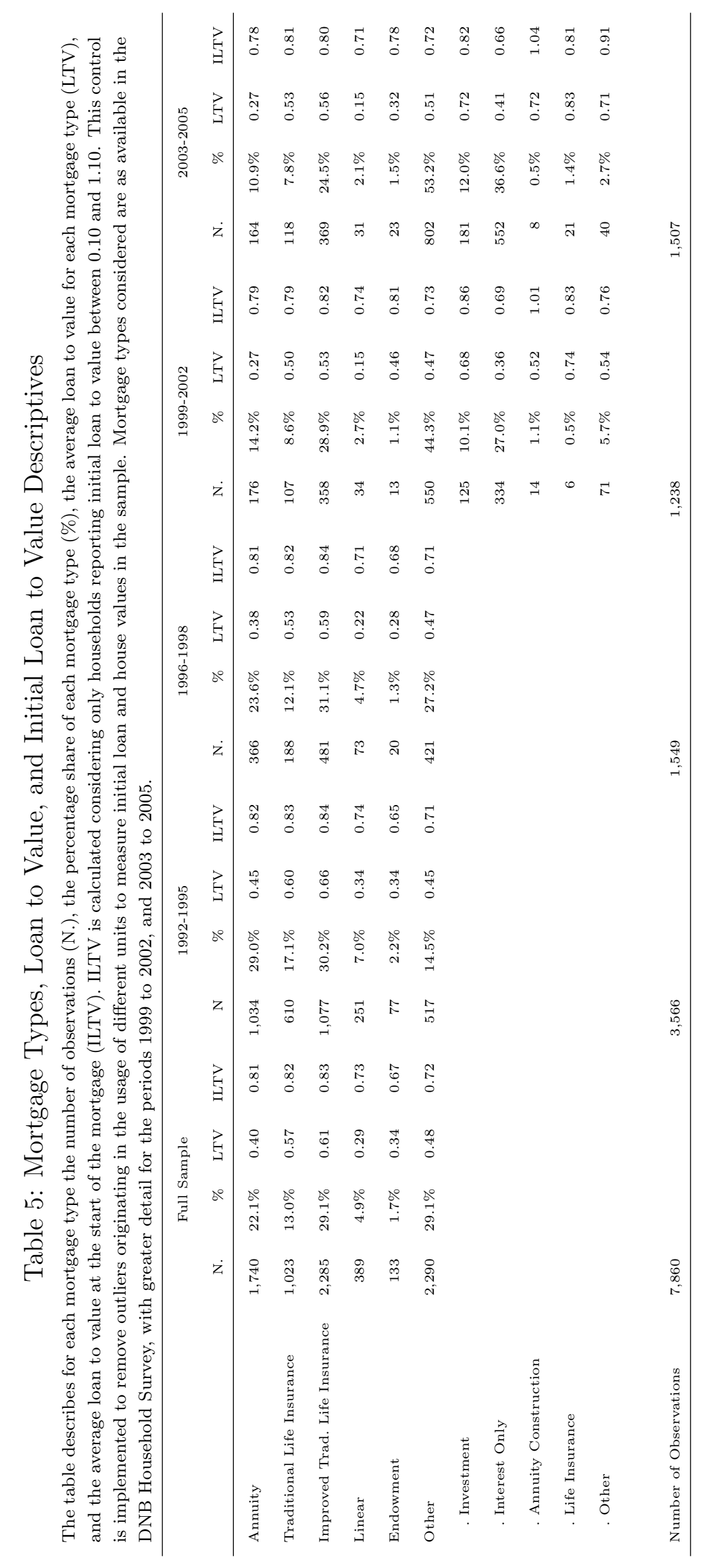




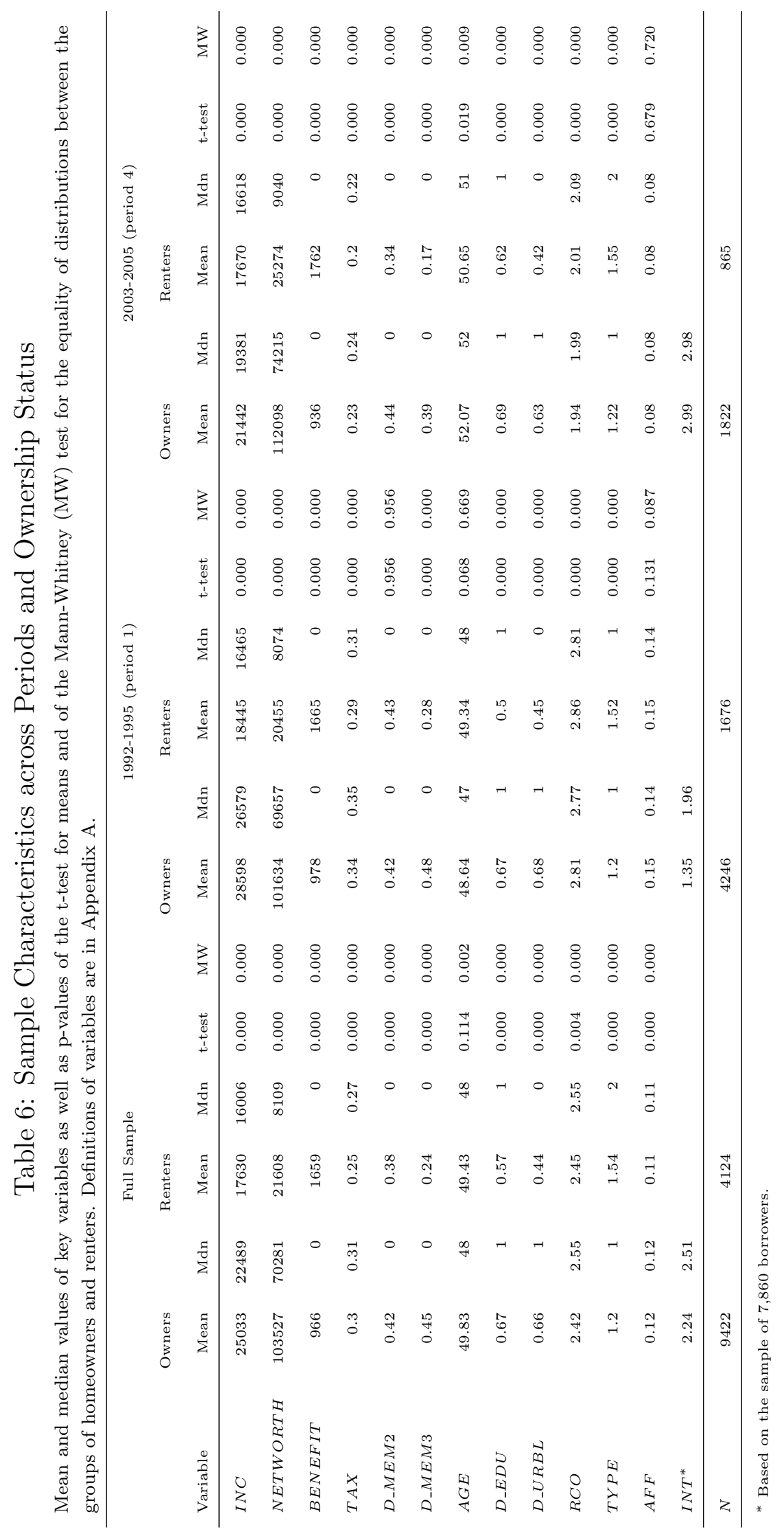




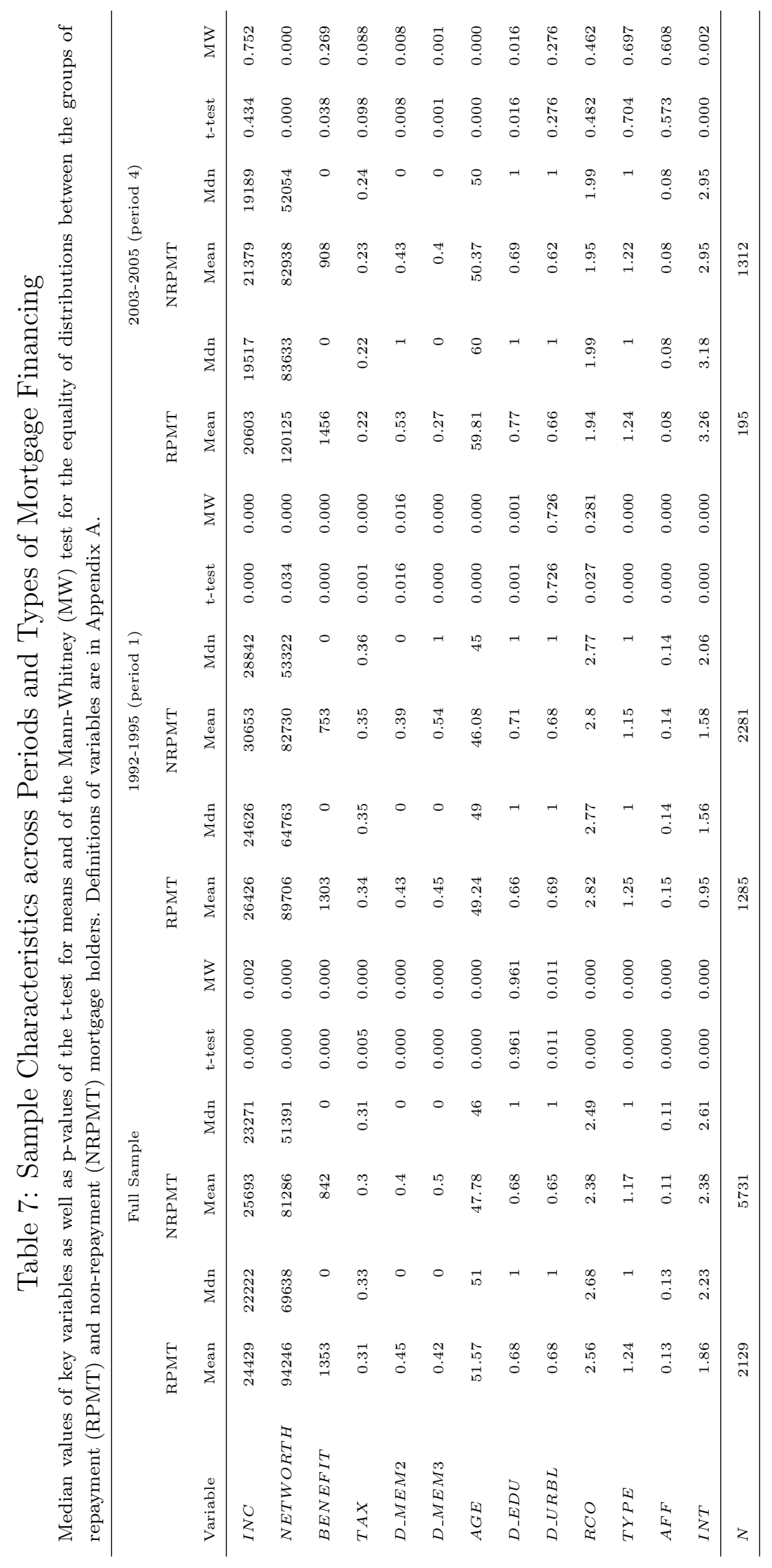


Table 8: Basic Regression Model of Mortgage Loan to Value

Results of the regression model of loan to value using different methods. Model 1 is estimated using OLS regression. Model 2 is estimated using a tobit regression. Model 3 is estimated using a Heckman model, which considers a sample selection equation describing the decision to own a house. Model 4 is estimated using a double hurdle model, with a sample selection equation describing the decision to own a house and censoring at the zero level of loan to value. Panel A describes the results of the regression equation for loan to value. Panel B presents the results of the selection equation for homeownership. The dependent variable in Panel B is binary and equals one if the household owns its home, and zero otherwise. Panel C presents model statistics. Independent variables are defined in Appendix A.



(cont'd) 


\begin{tabular}{|c|c|c|c|c|}
\hline (cont'd) & Model 1 & Model 2 & Model 3 & Model 4 \\
\hline \multicolumn{5}{|l|}{ Panel C: Model Statistics and Tests } \\
\hline Total Number of Observations & 7,860 & 9,422 & 11,984 & 13,546 \\
\hline No. Censored Observations & & 1,567 & 4,124 & 4,124 \\
\hline No. Uncensored Observations & & 7,855 & 7,860 & 9,422 \\
\hline$R^{2}$, Pseudo - $R^{2}$ & 0.40 & 0.50 & & \\
\hline Log-pseudolikelihood & & -2441.2 & -3973.1 & -4561.5 \\
\hline Wald $\chi^{2}$ testing joint significance of 2 equations & & & $\chi^{2}(12)=1556.9$ & \\
\hline $\mathrm{p}$-value for $\chi^{2}$ & & & 0.000 & \\
\hline Estimate of $\rho$ & & & 0.736 & 0.616 \\
\hline Wald $\chi^{2}$ Statistics testing $\rho=0$ (tests independence) & & & $\chi^{2}(1)=147.0$ & $\chi^{2}(1)=283.11$ \\
\hline $\mathrm{p}$-value for $\chi^{2}$ & & & 0.000 & 0.000 \\
\hline
\end{tabular}


Table 9: Extended Regression Model of Mortgage Loan to Value

Results of the regression model of loan to value using different methods. Models 1 and 2 are estimated using OLS regression. Models 3 and 4 are estimated using a Heckman model, which considers a sample selection equation describing the decision to own a house. Panel A describes the results of the regression equation for loan to value. Panel B presents model statistics. Independent variables are defined in Appendix A.

\begin{tabular}{|c|c|c|c|c|c|c|c|c|}
\hline \multirow{3}{*}{$\begin{array}{l}\text { Panel A: Regression Equation } \\
\text { Intercept }\end{array}$} & \multicolumn{2}{|c|}{ Model 1} & \multicolumn{2}{|c|}{ Model 2} & \multicolumn{2}{|c|}{ Model 3} & \multicolumn{2}{|c|}{ Model 4} \\
\hline & \multicolumn{8}{|c|}{ Dependent variable is $L T V$} \\
\hline & 0.6670 & 0.000 & 0.6770 & 0.000 & 0.4552 & 0.000 & 0.4638 & 0.000 \\
\hline$I N C V$ & 0.1416 & 0.186 & 0.1478 & 0.178 & 0.1054 & 0.353 & 0.1038 & 0.372 \\
\hline$I N C V * M T G T I M E$ & 0.0232 & 0.097 & 0.0229 & 0.108 & 0.0309 & 0.035 & 0.0315 & 0.034 \\
\hline$I N C V * M T G T I M E^{2}$ & -0.0006 & 0.110 & -0.0006 & 0.117 & -0.0008 & 0.048 & -0.0008 & 0.044 \\
\hline$I N C V * D \_N R P M T$ & 0.0740 & 0.587 & 0.0710 & 0.608 & 0.1167 & 0.409 & 0.1175 & 0.413 \\
\hline$I N C V * M T G T I M E * D \_N R P M T$ & -0.0074 & 0.613 & -0.0096 & 0.519 & -0.0125 & 0.403 & -0.0153 & 0.315 \\
\hline$I N C V * M T G T I M E^{2} * D_{-} N R P M T$ & 0.0005 & 0.279 & 0.0006 & 0.221 & 0.0006 & 0.217 & 0.0007 & 0.158 \\
\hline$S Q R T \_N E T W O R T H$ & -0.0007 & 0.000 & -0.0007 & 0.000 & -0.0005 & 0.000 & -0.0005 & 0.000 \\
\hline$B E N E F I T V$ & 0.5174 & 0.000 & 0.5091 & 0.000 & 0.4157 & 0.009 & 0.3984 & 0.014 \\
\hline$T A X$ & 0.1671 & 0.000 & 0.1576 & 0.000 & 0.2453 & 0.000 & 0.2362 & 0.000 \\
\hline$T A X * D \_A F T 97$ & -0.1071 & 0.000 & -0.0983 & 0.001 & -0.1250 & 0.000 & -0.1162 & 0.000 \\
\hline$D_{-} N R P M T$ & 0.1134 & 0.000 & & & 0.1170 & 0.000 & & \\
\hline$D_{-} M T G 2$ & & & 0.1465 & 0.000 & & & 0.1491 & 0.000 \\
\hline$D \_M T G 3$ & & & 0.1017 & 0.000 & & & 0.1071 & 0.000 \\
\hline$D \_M T G 4$ & & & -0.0555 & 0.000 & & & -0.0598 & 0.000 \\
\hline$D \_M T G 5$ & & & 0.0321 & 0.403 & & & 0.0191 & 0.612 \\
\hline$D \_M T G 6$ & & & 0.1017 & 0.000 & & & 0.1016 & 0.000 \\
\hline$D_{-} N R P M T * M T G T I M E$ & -0.0017 & 0.254 & -0.0019 & 0.196 & -0.0020 & 0.181 & -0.0022 & 0.150 \\
\hline MTGTIME & -0.0239 & 0.000 & -0.0240 & 0.000 & -0.0236 & 0.000 & -0.0238 & 0.000 \\
\hline$D \_M E M 3$ & 0.0450 & 0.001 & 0.0444 & 0.002 & 0.1127 & 0.000 & 0.1120 & 0.000 \\
\hline$D \_E D U$ & 0.0014 & 0.843 & 0.0011 & 0.874 & 0.0153 & 0.033 & 0.0152 & 0.031 \\
\hline$Y E A R$ & 0.0038 & 0.001 & 0.0038 & 0.001 & 0.0054 & 0.000 & 0.0054 & 0.000 \\
\hline$D_{-} U R B L$ & -0.0232 & 0.002 & -0.0243 & 0.001 & -0.0012 & 0.870 & -0.0020 & 0.790 \\
\hline \multicolumn{9}{|l|}{ Panel B: Model Statistics and Tests } \\
\hline Total Number of Observations & & 7,860 & & 7,860 & & 11,984 & & 11,984 \\
\hline No. Censored Observations & & & & & & 4,124 & & 4,124 \\
\hline No. Uncensored Observations & & & & & & 7,860 & & 7,860 \\
\hline$R^{2}$, Pseudo $-R^{2}$ & & 0.52 & & 0.53 & & & & \\
\hline Log-pseudolikelihood & & & & & & -3082.4 & & -3026.5 \\
\hline Wald $\chi^{2}$ testing joint significance of 2 equations & & & & & $\chi^{2}(2$ & $=3603$ & & $=3858$ \\
\hline $\mathrm{p}$-value for $\chi^{2}$ & & & & & & 0.000 & & 0.000 \\
\hline Estimate of $\rho$ & & & & & & 0.692 & & 0.704 \\
\hline Wald $\chi^{2}$ Statistics testing $\rho=0$ (tests independence) & & & & & $\chi^{2}(1$ & $=122.3$ & & $=143.6$ \\
\hline $\mathrm{p}$-value for $\chi^{2}$ & & & & & & 0.000 & & 0.000 \\
\hline
\end{tabular}


Table 10: Regression Model of Mortgage Category: All Observations

Results of the regression model explaining the probability of a household choosing a mortgage contract with non-repayment features. Models 1 and 2 are estimated using a standard probit specification. Models 3 and 4 are estimated using a Heckman probit specification, which considers a sample selection equation describing the decision to own a house. Panel A describes the decision to choose a mortgage contract with non-repayment features. The dependent variable in Panel A is binary and equals one if the household chooses a repayment mortgage, and zero otherwise. Panel B presents model statistics. Independent variables are defined in Appendix A.

\begin{tabular}{|c|c|c|c|c|c|c|c|c|}
\hline \multirow{3}{*}{$\begin{array}{l}\text { Panel A: Regression Equation } \\
\text { Intercept }\end{array}$} & \multicolumn{2}{|c|}{ Model 1} & \multicolumn{2}{|c|}{ Model 2} & \multicolumn{2}{|c|}{ Model 3} & \multicolumn{2}{|c|}{ Model 4} \\
\hline & \multicolumn{8}{|c|}{ Dependent variable equals 1 if repayment mortgage, 0 otherwise. } \\
\hline & 2.2765 & 0.000 & 3.9515 & 0.000 & 2.5459 & 0.000 & 4.1867 & 0.000 \\
\hline$I N C V$ & -0.2873 & 0.081 & -0.2914 & 0.078 & -0.3137 & 0.061 & -0.3187 & 0.058 \\
\hline$S Q R T \_N E T W O R T H$ & -0.0005 & 0.006 & -0.0005 & 0.007 & -0.0007 & 0.025 & -0.0007 & 0.026 \\
\hline$B E N E F I T V$ & -1.9475 & 0.001 & -1.9674 & 0.001 & -1.7922 & 0.004 & -1.8047 & 0.004 \\
\hline$T A X$ & 1.1250 & 0.000 & 1.0827 & 0.000 & 1.0611 & 0.000 & 1.0180 & 0.000 \\
\hline$T A X * D \_A F T 97$ & -0.1807 & 0.308 & -0.1367 & 0.453 & -0.1639 & 0.353 & -0.1214 & 0.502 \\
\hline$D \_M E M 2$ & 0.3218 & 0.002 & 0.3218 & 0.001 & 0.2749 & 0.026 & 0.2732 & 0.028 \\
\hline$D \_M E M 3$ & 0.3375 & 0.001 & 0.3382 & 0.001 & 0.2765 & 0.042 & 0.2749 & 0.044 \\
\hline$A G E$ & -0.0719 & 0.000 & -0.0727 & 0.000 & -0.0755 & 0.000 & -0.0763 & 0.000 \\
\hline$D \_E D U$ & 0.0634 & 0.246 & 0.0676 & 0.215 & 0.0507 & 0.367 & 0.0543 & 0.333 \\
\hline$Y E A R$ & 0.0834 & 0.000 & & & 0.0816 & 0.000 & & \\
\hline$D \_P E R 2$ & & & -0.0821 & 0.118 & & & -0.0792 & 0.132 \\
\hline$D \_P E R 3$ & & & -0.0132 & 0.897 & & & -0.0091 & 0.929 \\
\hline$D \_P E R 4$ & & & 0.1420 & 0.204 & & & 0.1419 & 0.203 \\
\hline$D \_U R B L$ & -0.0467 & 0.445 & -0.0466 & 0.445 & -0.0657 & 0.316 & -0.0663 & 0.311 \\
\hline$A F F$ & -3.0258 & 0.244 & -12.7535 & 0.000 & -3.0056 & 0.246 & -12.4719 & 0.000 \\
\hline \multicolumn{9}{|l|}{ Panel B: Model Statistics and Tests } \\
\hline Total Number of Observations & & 7,860 & & 7,860 & & 11,984 & & 11,984 \\
\hline No. Censored Observations & & & & & & 4,124 & & 4,124 \\
\hline Log-pseudolikelihood & & -4167.4 & & -4170.7 & & -9292.3 & & -9296.1 \\
\hline Wald $\chi^{2}$ testing joint significance of 2 equations & $\chi^{2}(13)$ & $=417.3$ & $\chi^{2}(15$ & $=435.5$ & $\chi^{2}(13$ & $=426.6$ & $\chi^{2}(15$ & $=445.4$ \\
\hline $\mathrm{p}$-value for $\chi^{2}$ & & 0.000 & & 0.000 & & 0.000 & & 0.000 \\
\hline Estimate of $\rho$ & & & & & & -0.146 & & -0.150 \\
\hline Wald $\chi^{2}$ statistics testing $\rho=0$ (independence test) & & & & & $\chi^{2}$ & $=0.68$ & $\chi^{2}$ & $=0.70$ \\
\hline $\mathrm{p}$-value for $\chi^{2}$ & & & & & & 0.411 & & 0.403 \\
\hline
\end{tabular}


Table 11: Regression Model of Mortgage Category: Periods 1992-1995 and 2003-2005

Results of the regression model explaining the probability of a household choosing a mortgage contract with non-repayment features. Models 1 and 2 correspond to years 1992-1995 (period 1). Models 3 and 4 correspond to years 2003-2005 (period 4). Models 1 and 3 are estimated using a standard probit specification. Models 2 and 4 are estimated using a Heckman probit specification, which considers a sample selection equation describing the decision to own a house. Panel A describes the decision to choose a mortgage contract with non-repayment features. The dependent variable in Panel A is binary and equals one if the household chooses a repayment mortgage, and zero otherwise. Panel B presents model statistics. Independent variables are defined in Appendix A.

\begin{tabular}{|c|c|c|c|c|c|c|c|c|}
\hline \multirow{3}{*}{$\begin{array}{l}\text { Panel A: Regression Equation } \\
\text { Intercept }\end{array}$} & \multicolumn{2}{|c|}{ Model 1} & \multicolumn{2}{|c|}{ Model 2} & \multicolumn{2}{|c|}{ Model 3} & \multicolumn{2}{|c|}{ Model 4} \\
\hline & \multicolumn{8}{|c|}{ Dependent variable equals 1 if repayment mortgage, 0 otherwise. } \\
\hline & -1.7404 & 0.333 & -0.8931 & 0.618 & 15.2480 & 0.194 & 14.5384 & 0.214 \\
\hline$I N C V$ & -0.2897 & 0.227 & -0.4081 & 0.081 & -0.8086 & 0.088 & -0.7554 & 0.106 \\
\hline$S Q R T \_N E T W O R T H$ & -0.0003 & 0.211 & -0.0009 & 0.002 & -0.0007 & 0.061 & -0.0003 & 0.661 \\
\hline$B E N E F I T V$ & -2.4669 & 0.001 & -2.0332 & 0.007 & -3.7617 & 0.082 & -4.1255 & 0.057 \\
\hline$T A X$ & 0.9753 & 0.000 & 0.8448 & 0.000 & 0.8447 & 0.116 & 0.9296 & 0.094 \\
\hline$D \_M E M 2$ & 0.3629 & 0.001 & 0.2461 & 0.036 & 0.2446 & 0.172 & 0.3267 & 0.103 \\
\hline$D \_M E M 3$ & 0.4228 & 0.000 & 0.2683 & 0.037 & 0.0468 & 0.812 & 0.1643 & 0.495 \\
\hline$A G E$ & -0.0669 & 0.000 & -0.0805 & 0.000 & -0.1311 & 0.000 & -0.1255 & 0.001 \\
\hline$A G E^{2}$ & 0.0005 & 0.006 & 0.0007 & 0.000 & 0.0009 & 0.007 & 0.0008 & 0.015 \\
\hline$Y E A R$ & 0.3185 & 0.003 & 0.3076 & 0.004 & -0.1896 & 0.484 & -0.1854 & 0.491 \\
\hline$D_{-} U R B L$ & -0.0230 & 0.727 & -0.0896 & 0.187 & -0.0788 & 0.554 & -0.0448 & 0.743 \\
\hline$A F F$ & 17.3647 & 0.084 & 17.3052 & 0.079 & -94.5181 & 0.374 & -92.2506 & 0.383 \\
\hline \multicolumn{9}{|l|}{ Panel B: Model Statistics and Tests } \\
\hline Total Number of Observations & & 3,566 & & 5,242 & & 1,507 & & 2,372 \\
\hline No. Censored Observations & & & & 1,676 & & & & 865 \\
\hline No. Uncensored Observations & & & & 3,566 & & & & 1,507 \\
\hline$R^{2}$, Pseudo - $R^{2}$ & & 0.045 & & & & 0.105 & & \\
\hline Log-pseudolikelihood & & -2225.8 & & -4250.3 & & -519.8 & & -1635.3 \\
\hline Wald $\chi^{2}$ testing joint significance of 2 equations & $\chi^{2}(12)$ & $=169.6$ & $\chi^{2}(12$ & $=171.6$ & $\chi^{2}(12)$ & $=63.13$ & $\chi^{2}(12)$ & $=57.38$ \\
\hline Wald $\chi^{2}$ Statistics testing $\rho=0$ (tests independence) & & & $\chi^{2}($ & $=8.34$ & & & $\chi^{2}($ & $=0.67$ \\
\hline $\mathrm{p}$-value for $\chi^{2}$ & & & & 0.004 & & & & 0.414 \\
\hline
\end{tabular}




\section{Table 12: Regression Models of Mortgage Interest Rate}

Results of the regression model explaining the mortgage interest rate. Model 1 is estimated using the 2SLS method, with predicted values of $L T V$ obtained as a result of stage 1. Models 2-4 are based using the treatment regression, where the mortgage type is a binary treatment variable. Models 1 and 2 are based on the entire sample of the borrowers, model 3 corresponds to years 1992-1995 (period 1), whereas model 4 corresponds to years 2003-2005 (period 4). Panel A describes the determinants of the mortgage interest rate, INT. Panel B presents model statistics. Independent variables are defined in Appendix A.

\begin{tabular}{|c|c|c|c|c|c|c|c|c|}
\hline \multirow{3}{*}{$\begin{array}{l}\text { Panel A: Regression Equation } \\
\text { Intercept }\end{array}$} & \multicolumn{2}{|c|}{ Model 1} & \multicolumn{2}{|c|}{ Model 2} & \multicolumn{2}{|c|}{ Model 3} & \multicolumn{2}{|c|}{ Model 4} \\
\hline & \multicolumn{8}{|c|}{ Dependent variable is $I N T$} \\
\hline & 0.0448 & 0.921 & -3.3576 & 0.000 & -3.7419 & 0.000 & 2.4617 & 0.005 \\
\hline$L T V$ & 1.0208 & 0.000 & & & & & & \\
\hline$M T G_{-} T Y P E$ & & & 3.5472 & 0.000 & 3.8396 & 0.000 & -0.4897 & 0.411 \\
\hline$S Q R T \_I N C$ & -0.0047 & 0.000 & -0.0033 & 0.000 & -0.0023 & 0.002 & 0.0009 & 0.268 \\
\hline$S Q R T_{-} B E N E F I T$ & -0.0018 & 0.049 & 0.0012 & 0.267 & 0.0020 & 0.160 & -0.0007 & 0.608 \\
\hline$D \_M E M 2$ & -0.3754 & 0.000 & -0.5774 & 0.000 & -0.8079 & 0.000 & -0.1208 & 0.280 \\
\hline$D \_M E M 3$ & -0.2894 & 0.001 & -0.5379 & 0.000 & -0.9055 & 0.000 & -0.0884 & 0.470 \\
\hline$A G E$ & 0.1010 & 0.000 & 0.1496 & 0.000 & 0.1513 & 0.000 & 0.0545 & 0.004 \\
\hline$A G E^{2}$ & -0.0008 & 0.000 & -0.0012 & 0.000 & -0.0012 & 0.000 & -0.0006 & 0.001 \\
\hline$D_{-} U R B L$ & -0.1957 & 0.001 & -0.1464 & 0.072 & -0.1790 & 0.101 & -0.2604 & 0.001 \\
\hline \multicolumn{9}{|l|}{ Panel B: Model Statistics and Tests } \\
\hline Number of Observations & & 7,860 & & 7,860 & & 3,566 & & 1,507 \\
\hline$R^{2}$ & & 0.001 & & & & & & \\
\hline Log-pseudolikelihood & & & & -19479 & & -8901.0 & & -2827.8 \\
\hline Wald $\chi^{2}$ testing joint significance of 2 equations & & & $\chi^{2}(9$ & $=2952$ & $\chi^{2}$ & $=3331$ & & $=32.56$ \\
\hline $\mathrm{p}$-value for $\chi^{2}$ & & & & 0.000 & & 0.000 & & 0.000 \\
\hline Estimate of $\rho$ & & & & -0.895 & & -0.970 & & 0.056 \\
\hline Wald $\chi^{2}$ Statistics testing $\rho=0$ (tests independence) & & & $\chi^{2}(1$ & $=2135$ & $\chi^{2}$ & $=1746$ & & $=0.04$ \\
\hline $\mathrm{p}$-value for $\chi^{2}$ & & & & 0.000 & & 0.000 & & 0.845 \\
\hline
\end{tabular}

